\title{
Beremendia (Mammalia, Soricidae) remains from the late Early Pleistocene \\ Somssich Hill 2 locality (Southern Hungary) and their taxonomic, biostratigraphical, palaeoecological and palaeobiogeographical relations
}

\author{
D. BotKa \& L. MÉsZÁros \\ Eötvös Loránd University, Department of Palaeontology, \\ H-1117 Budapest, Pázmány Péter sétány 1/C, Hungary. \\ E-mail:botkadani@gmail.com,salpin@freemail.bu
}

\begin{abstract}
Beremendia fissidens and B. minor remains of the late Early Pleistocene vertebrate fauna of the Somssich Hill 2 locality are described. B. minor is reported here as a new element in the site. This record emended the stratigraphic range of this species to the Early Biharian Stage, Nagyharsányhegy Phase (ca. $900 \mathrm{ka}$ ). The detailed morphological and morphometrical studies gave a chance to make a new differential diagnosis between the two forms. Both of them might have been characterized by special nutrition strategy (poisoning snails and other small animals by their grooved lower incisor and storing them in their pits) and they could have lived in forest- and bushcovered lake-, or riversides. The European stratigraphical and palaeobiogeographical occurrences of the genus are summarized on the basis of published literature. With 30 figures and 3 tables.
\end{abstract}

Key words - Beremendia fissidens, Beremendia minor, Early Pleistocene, Soricidae, Somssich Hill, Villány Hills, Hungary

\section{INTRODUCTION}

The Somssich Hill 2 site is one of the most important Pleistocene vertebrate localities of Hungary. It was discovered by Dénes Jánossy and György Topál in 1975. The excavation led by them between 1975 and 1985 yielded rich Pleistocene fauna, of which preliminary list is given by JÁNossy (1986). The molluscan fauna of the locality was elaborated by Krolopp (2000), and some mammal groups were also described by János Hír (cricetids) and Dénes Jánossy (lemmings and arvicolids) (Hír 1998; JÁnOssy 1983, 1990). Most of the Somssich Hill 2 material is under elaboration in the Department of Palaeontology and Geology of Hungarian Natural History Museum, by the cooperative research group of the Hungarian Academy of Sciences, the Hungarian Natural History Museum and the Eötvös Loránd University (OTKA K104506; project leader: Piroska Pazonyi). Up to now mainly preliminary reports were published on the results of this work 
(Botka \& MÉszáros 2014; Mészáros et al. 2013; Pazonyi et al. 2013a, b; PAZONyi \& Virág 2013a, $b$; SZENTESI 2013, 2014a).

A great number of soricid fossils were found in the Somssich Hill material. Seven shrew species were mentioned by BOT KA \& MÉszáros (2014), and two of them (Beremendia fissidens, B. minor) are discussed here in detail.

\section{LOCALITY}

The Somssich Hill 2 site is located ca. $500 \mathrm{~m}$ west of Villány, on the top of the Somssich Hill (today known as Villány Hill) in Southern Hungary, Villány Hills (GPS coordinates: N 4552' 26.66", E 18² 26' 32.71"; EOVX = 58998, EOVY $=603025)$ (Fig. 1).

The locality is a sediment-filled karst fissure in the Jurassic limestone of the Villány Hills. Fifty layers were separated within the excavated infilling sediment (each layers are $20-30 \mathrm{~cm}$ in thickness). The sediment was loess-like yellow aleurite in the upper layers, but became red and more clayey down from the layer 28 (KoRdos 1991). The cave was excavated in depth of ca. $9.5 \mathrm{~m}$ (JÁnOSsY 1999).

\section{MATERIAL AND METHODS}

The fossil material of the locality is stored in the Department of Palaeontology and Geology of the Hungarian Natural History Museum, Budapest. Several shrew species were identified in the material collected by Dénes Jánossy (BOTKA \& MÉszÁros 2014). The fossil bones are poorly preserved, most of them are fragmentary, the complete mandibles and maxillae are relatively rare. The Beremendia shrews are well distinguished from the other shrew species of the locality by the large-sized elements (skull elements, teeth and humeri).

The fifty layers yielded 169 B. fissidens and 11 B. minor remains (minimum number of individuals: 61 , and 8 , respectively). At the determination of the minimum number of individuals all the bone elements and teeth were taken into consideration. During the anatomical description and measurements of specimens the method presented by REUMER (1984) was followed.

The measurements were made by a calibrated eyepiece micrometer of a Nikon SMZ800 microscope and were given in $\mathrm{mm}$. The $\mathrm{R}$ 3.1.1. software was used for making the morphometrical analyses. The SEM photos were taken by a Hitachi S-2600N Variable Pressure Scanning Electron Microscope (VPSEM).

The abbreviations in the description and the measurements are used as follows: $\mathrm{I}=$ incisor, $\mathrm{A}=$ antemolar, $\mathrm{P}=$ premolar, $\mathrm{M}=$ molar, $\mathrm{M}^{\mathrm{x}}=$ upper tooth, $\mathrm{M}_{\mathrm{x}}=$ lower tooth, $\mathrm{L}=$ length, $\mathrm{W}=$ width, $\mathrm{H}=$ height, $\mathrm{BL}=$ buccal length, $\mathrm{LL}=$ lingual 
length, $\mathrm{AW}=$ anterior width, $\mathrm{PW}=$ posterior width, $\mathrm{n}=$ number of specimens, min. $=$ minimum, max. $=$ maximum, $S D=$ standard deviation, $\mathrm{MNI}=$ minimum number of individuals.

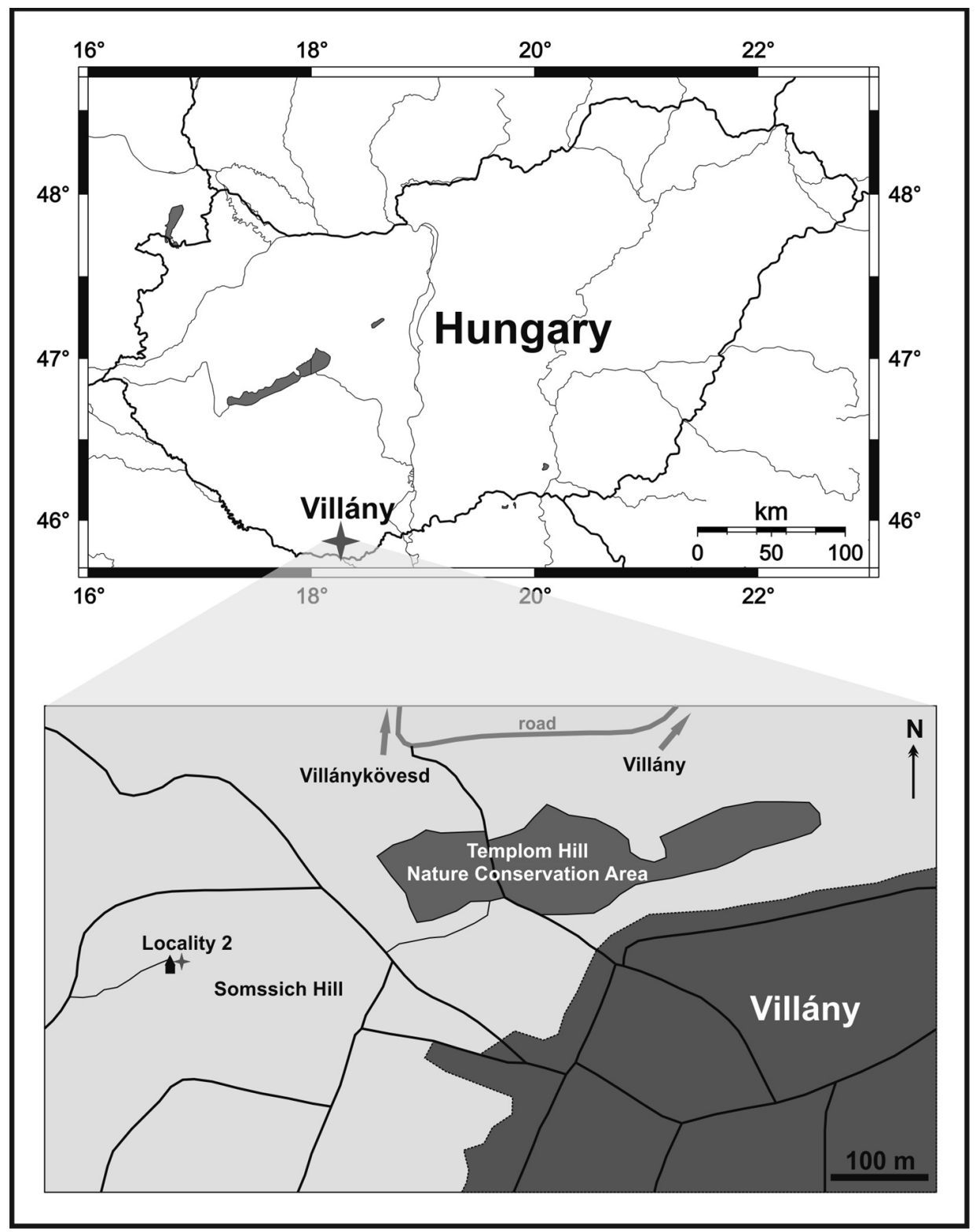

Fig. 1. The geographical situation of Somssich Hill 2 locality (after PAZONYi et al. 2013a) 


\section{SYSTEMATIC DESCRIPTION}

Phylum Vertebrata Linnaeus, 1758

Classis Mammalia Linnaeus, 1758

Order Eulipotyphla Waddell et al., 1999

Family Soricidae Fischer von Waldheim, 1817

Subfamily Soricinae Fischer von Waldheim, 1817

Tribe Beremendiini Reumer, 1984

Genus Beremendia Kormos, 1934

Upper incisor strongly fissident; teeth heavily pigmented; Blarinini-like condyle with broad interarticular area and anteriorly placed lower facet; lower incisor acuspulate; entoconid crests are present (REUMER 1984).

This is the only monogeneric tribe (Beremendiini) among the Soricinae, comprising only the extinct genus Beremendia. Separation of this tribe from the other tribes is based on the intermediate position of its morphology between the Soriculini (bifid $\mathrm{I}^{1}$ and presence of entoconid crests) and the Blarinini (structure of the condyle and intense dark red pigmentation) (REUMER 1984).

\section{Beremendia fissidens (Petényi, 1864)}

(Figs 2-12, 16)

1864 Crossopus fissidens n. gen. n. sp. - PetéNYi, pp. 60-70, pl. I, fig. 5.

1911 Neomys fissidens (Petényi) - Kormos, pp. 156-158, pl. VII, figs 1-3.

1930 Neomys (?) fissidens (Petényi) - Heller, pp. 254-258, text-figs 2-4, pl. XV, figs 1-3.

1930 Beremendia fissidens n. gen. (Petényi) - Kormos, pp. 43-44, 57.

1934 Beremendia fissidens (Petényi) - Kormos, pp. 299-301, fig. 33.

1936 Beremendia fissidens (Petényi) - HELler, pp. 107-108, pl. VII, figs 1-2.

1949 Beremendia fissidens (Petényi) - Friant, pp. 256-257, fig. 17.

1958 Beremendia fissidens (Petényi) - Kowals KI, pp. 13-14, fig. 4.

1959 Beremendia fissidens (Petényi) - SULIMS KI, pp. 152-154, tab. 7, text-fig. 4: 1a-f, pl. III, fig. 7.

1966 Beremendia fissidens (Petényi) - FEJFAR, figs 4f-j, 5f-h, 10d, h.

1967 Beremendia fissidens (Petényi) - REPENNING, pp. 50-51, fig. 35.

1976 Beremendia fissidens (Petényi) - Freudent hal et al., pl. I. figs 7-8.

1976 Beremendia fissidens (Petényi) - RzeBik-Kowalska, pp. 360-368, tabs I-III, X, figs 1-11, $21,23,25,28-29,33-35$.

1979 Nectogalinia altaica n. gen. n. sp. - GuReEv, p. 458, fig. 235.

1984 Beremendia fissidens (Petényi) - Reumer, pp. 131-138, text-fig. 16, pl. 32, figs 1-13, pl. 33, figs 1-6, pl. 34, figs 1-4, pl. 35, figs 1-2.

1996 Beremendia fissidens (Petényi) - Dahlmann \& Storch, p. 185, tab. 3.

2002 Beremendia fissidens (Petényi) - Aguilar et al., p. 24, pl. II, figs 11-14.

2003 Beremendia fissidens (Petényi) - Popov, pp. 60-62, tab. V, figs 7-8.

2004 Beremendia fissidens (Petényi) - SUÁREZ \& MeIn, pp. 122-123, fig. 8c-e.

2006 Beremendia fissidens (Petényi) - HARRIson et al., pp. 121-124, figs 1a-c, 3c, 4a-b.

2007 Beremendia cf. fissidens (Petényi) - ČERMÁK et al., fig. 3a, c. 
2007 Beremendia fissidens (Petényi) - CuenCA-Bescós \& RoFes, pp. 113-115, fig. 3a.

2007 Beremendia fissidens (Petényi) - HoRÁčEK et al., pp. 459-460, pl. 2, figs 3-4.

2009 Beremendia fissidens (Petényi) - Rofes \& CuencA-Bescós, pp. 24-30, tab. 1, figs 3-5.

2010 Beremendia fissidens (Petényi) - Furió et al., pp. 929-936, figs 2-8.

2012 Beremendia fissidens (Petényi) - HellmuNd \& ZiEgler, p. 81, pl. 1, fig. 3.

2013 Beremendia fissidens (Petényi) - CuenCA-Bescós et al., fig. 4d.

2013 Beremendia fissidens (Petényi) - RzEBIK-KowalsKA, pp. 25-28, tabs 30-32, fig. 5: 7.

2014 Beremendia fissidens (Petényi) - BENNÀsAR et al., tab. 2, figs 3-4.

in press Beremendia fissidens (Petényi) - BоткA \& MÉszáros, tabs 1-2, pl. I, figs 1-7.

Type material - Crossopus fissidens Petényi, 1864: Hungarian Natural History Museum, Department of Palaeontology and Geology, inventory number V 61.1585. Syntypes: 1 skull fragment, 2 left and 2 right maxillae, 13 left and 15 right mandibles, 1 condyle and $8 \mathrm{I}_{1}$.

Type locality - Beremend limestone quarry (locality 2), Villány Hills, Hungary, Upper Pliocene (Villányian Stage, Beremend Phase, MN 16).

Studied material - Somssich Hill 2 locality: 13 left maxillary fragments, 11 right maxillary fragments, 9 left mandibles, 6 right mandibles, 20 left mandible fragments, 18 right mandible fragments, 8 left $\mathrm{I}^{1}, 13$ right $\mathrm{I}^{1}, 5$ left $\mathrm{P}^{4}, 6$ right $\mathrm{P}^{4}, 5$ left $\mathrm{M}^{1}, 4$ right $\mathrm{M}^{1}, 3$ left $\mathrm{M}^{2}, 2$ right $\mathrm{M}^{2}, 10$ left $\mathrm{I}_{1}, 5$ right $\mathrm{I}_{1}, 1$ left $\mathrm{A}_{1}, 1$ left $\mathrm{A}_{2}, 8$ left $M_{1}, 6$ right $M_{1}, 3$ left $M_{2}, 7$ right $M_{2}, 1$ right $M_{3}$ and 4 humeri.

Measurements - Table 1.

Dental formula $-153 / 123$ or $143 / 123$ ( $\mathrm{A}^{4}$ is missing from a few specimens).

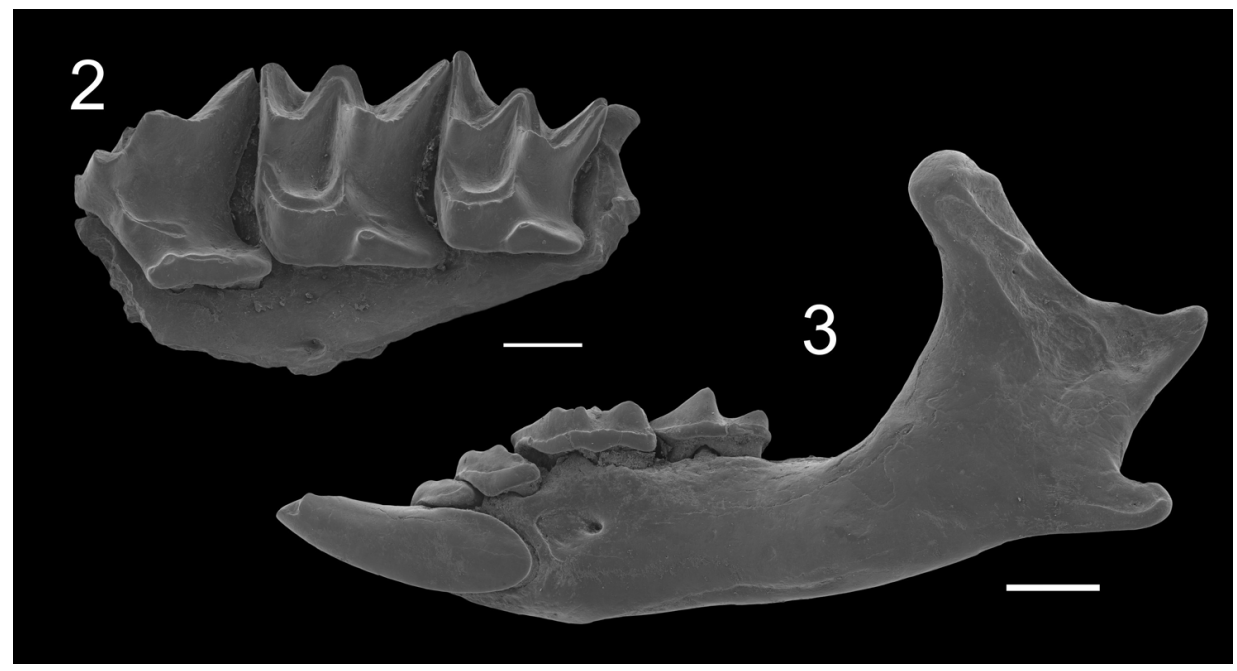

Figs 2-3. Beremendia fissidens (Petényi, 1864), Somssich Hill 2. 2 = left maxillary fragment with $\mathrm{P}^{4}-\mathrm{M}^{2}$, layer 14, occlusal view, scale bar: $1 \mathrm{~mm}, 3=$ left mandible with $\mathrm{I}_{1}-\mathrm{M}_{2}$, layer 30 , buccal view, scale bar: $2 \mathrm{~mm}$ 
Table 1. Measurements of Beremendia fissidens teeth from Somssich Hill 2 (for the abbreviations see "Material and methods")

\begin{tabular}{llccccc}
\hline & & $\mathrm{n}(\mathrm{pcs})$ & min. $(\mathrm{mm})$ & mean $(\mathrm{mm})$ & max. $(\mathrm{mm})$ & $\mathrm{SD}(\mathrm{mm})$ \\
\hline $\mathrm{I}^{1}$ & $\mathrm{~L}$ & 9 & 3.33 & 3.62 & 4.20 & 0.2687 \\
& $\mathrm{H}$ & 9 & 2.10 & 2.31 & 2.50 & 0.1422 \\
\hline $\mathrm{P}^{1}$ & $\mathrm{BL}$ & 17 & 2.47 & 2.79 & 2.93 & 0.1167 \\
& $\mathrm{LL}$ & 17 & 1.40 & 1.55 & 1.80 & 0.1202 \\
& $\mathrm{~W}$ & 17 & 2.40 & 2.58 & 2.77 & 0.1185 \\
\hline $\mathrm{M}^{1}$ & $\mathrm{LL}$ & 18 & 2.20 & 2.35 & 2.57 & 0.1004 \\
& $\mathrm{BL}$ & 18 & 2.20 & 2.46 & 2.70 & 0.1565 \\
& AW & 18 & 2.33 & 2.57 & 2.73 & 0.1091 \\
& $\mathrm{PW}$ & 17 & 2.33 & 2.58 & 2.80 & 0.1214 \\
\hline $\mathrm{M}^{2}$ & $\mathrm{LL}$ & 7 & 1.53 & 1.78 & 2.00 & 0.1665 \\
& $\mathrm{BL}$ & 7 & 1.80 & 2.00 & 2.20 & 0.1540 \\
& AW & 7 & 2.27 & 2.45 & 2.67 & 0.1359 \\
& $\mathrm{PW}$ & 7 & 1.67 & 1.88 & 2.00 & 0.1258 \\
\hline $\mathrm{I}_{1}$ & $\mathrm{~L}$ & 4 & 5.93 & 6.33 & 6.60 & 0.2961 \\
& $\mathrm{H}$ & 4 & 1.47 & 1.77 & 2.00 & 0.2211 \\
\hline $\mathrm{M}_{1}$ & $\mathrm{~L}$ & 20 & 2.67 & 2.85 & 3.00 & 0.1110 \\
& $\mathrm{~W}$ & 20 & 1.47 & 1.61 & 1.73 & 0.0873 \\
\hline $\mathrm{M}_{2}$ & $\mathrm{~L}$ & 24 & 1.93 & 2.30 & 2.47 & 0.1302 \\
& $\mathrm{~W}$ & 24 & 1.33 & 1.44 & 1.63 & 0.0764 \\
\hline $\mathrm{M}_{3}$ & $\mathrm{~L}$ & 14 & 1.50 & 1.62 & 1.73 & 0.0834 \\
& $\mathrm{~W}$ & 14 & 0.83 & 0.95 & 1.13 & 0.0834 \\
\hline & & & & & &
\end{tabular}

Original diagnosis - The original diagnosis of Petényi (in old Hungarian language) highlighted the bifid upper incisor, the acuspulate lower incisor and the relative position of the incisors and antemolars as specific morphological characters. The new species was described as "Crossopus” fissidens and was classified to the group of the red-toothed water shrews (after PeténYi 1864).

Emended diagnosis - Teeth intensively stained dark red. $\mathrm{I}^{1}$ is strongly fissident with a bifid apex. Four upper antemolars are present. $A^{1}$ and $A^{2}$ are of about equal size, $\mathrm{A}^{3}$ is smaller and $\mathrm{A}^{4}$ is smaller again. $\mathrm{A}^{4}$ is reduced, hidden and not visible in buccal view or is lacking. The posterior emargination is moderate on $\mathrm{P}^{4}, \mathrm{M}^{1}$ and $\mathrm{M}^{2}$. The parastyle of the $\mathrm{M}^{1}$ is moderately developed. $\mathrm{M}^{3}$ is relatively small. $\mathrm{I}_{1}$ is grooved, acuspulate, the apex curves upwards. $\mathrm{A}_{2}$ is bicuspid and has a posterolingual basin. $M_{3}$ is reduced. The ramus is strong and robust. The coro- 
noid process is stout, anterolaterally curved; the angle of the curve may vary. The angular process is short and flat. The external pterygoid fossa is definitely or less deeply pocketed. The upper facet is narrow; its shape may vary from elliptic to oval. The interarticular area is broad with a lingual margin. The lower facet leans strongly anteriorly and it is not visible in buccal view. The internal temporal fossa is small, deep and pocketed (after REUMER 1984).

Anatomical description - Some detailed anatomical descriptions were already published on B. fissidens (RzEBIK-KOWALSKA 1976; REUMER 1984; ROFES \& Cuenca-Bescós 2009; BotKa \& Mészáros in press). Therefore, only the most important morphological characters and the differential diagnosis between the two discussed forms are presented in this article.

Mandible - The mandibular body is robust, strongly built, slightly leans laterally. The symphysis terminates below the posterior root of $M_{1}$. The ascending ramus is anteroposteriorly broad and leans strongly medially. The coronoid process is narrow, short, stout and leans anteriorly in lateral view. The coronoid

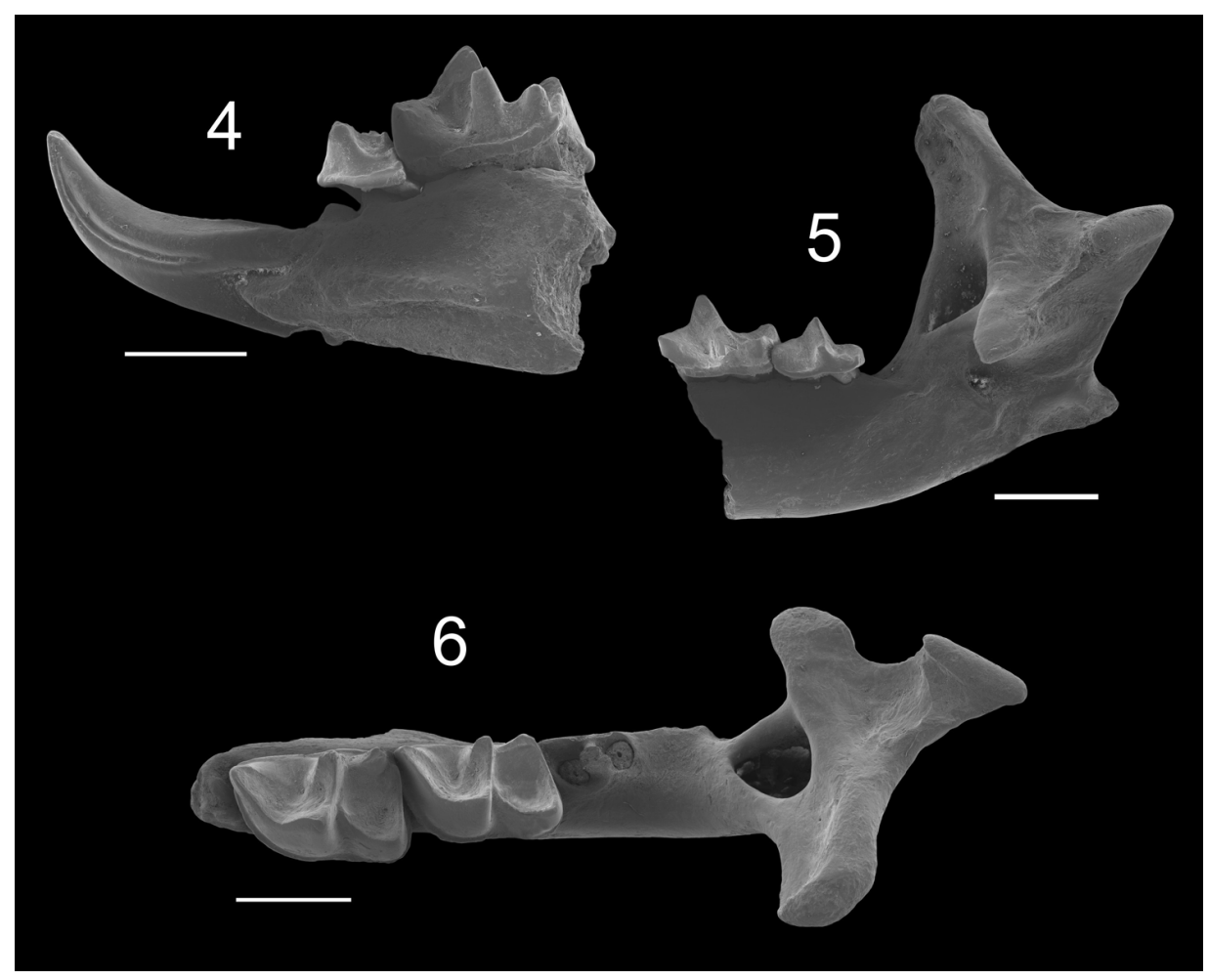

Figs 4-6. Beremendia fissidens (Petényi, 1864), Somssich Hill 2, scale bar: $2 \mathrm{~mm} .4$ = right mandible fragment with $I_{1}, A_{2}$ and $M_{1}$, layer 13 , lingual view, 5 = right mandible fragment with $M_{2}-M_{3}$, layer 28 , lingual view, $6=$ left mandible fragment with $M_{1}-M_{2}$, layer 32 , occlusal view 


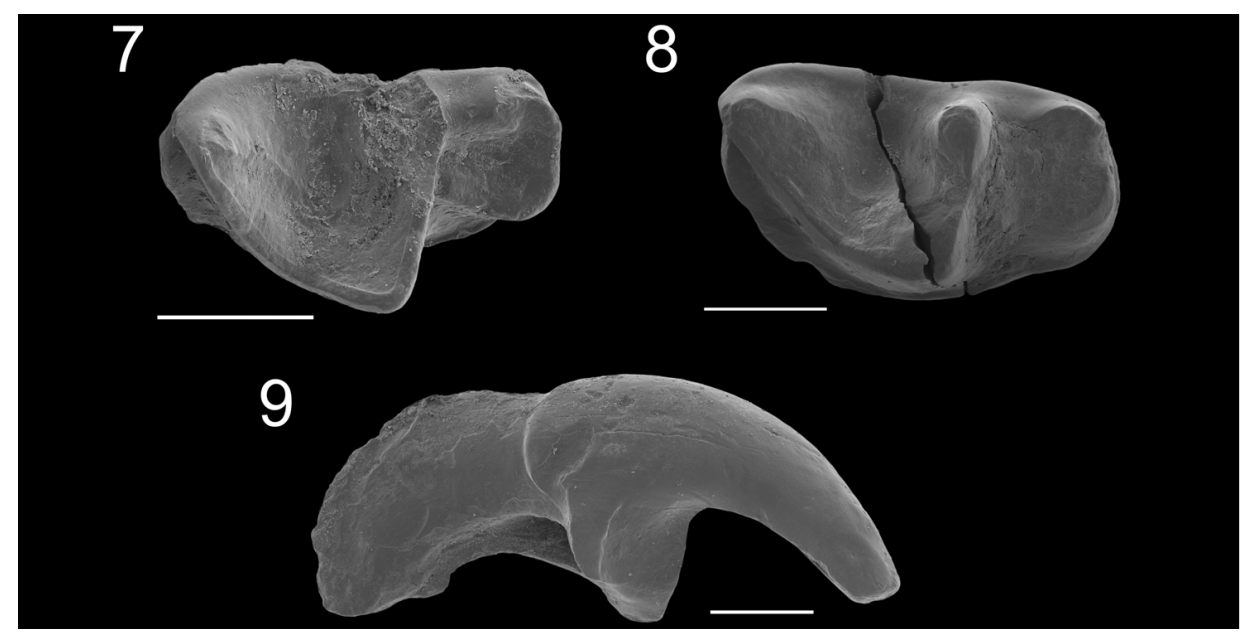

Figs 7-9. Beremendia fissidens (Petényi, 1864), Somssich Hill 2, scale bar: $1 \mathrm{~mm} .7=$ left $\mathrm{M}_{3}$, layer 32 , occlusal view, $8=$ left $\mathrm{M}_{3}$, layer 5 , occlusal view, $9=$ left $\mathrm{I}^{1}$, layer 11 , buccal view

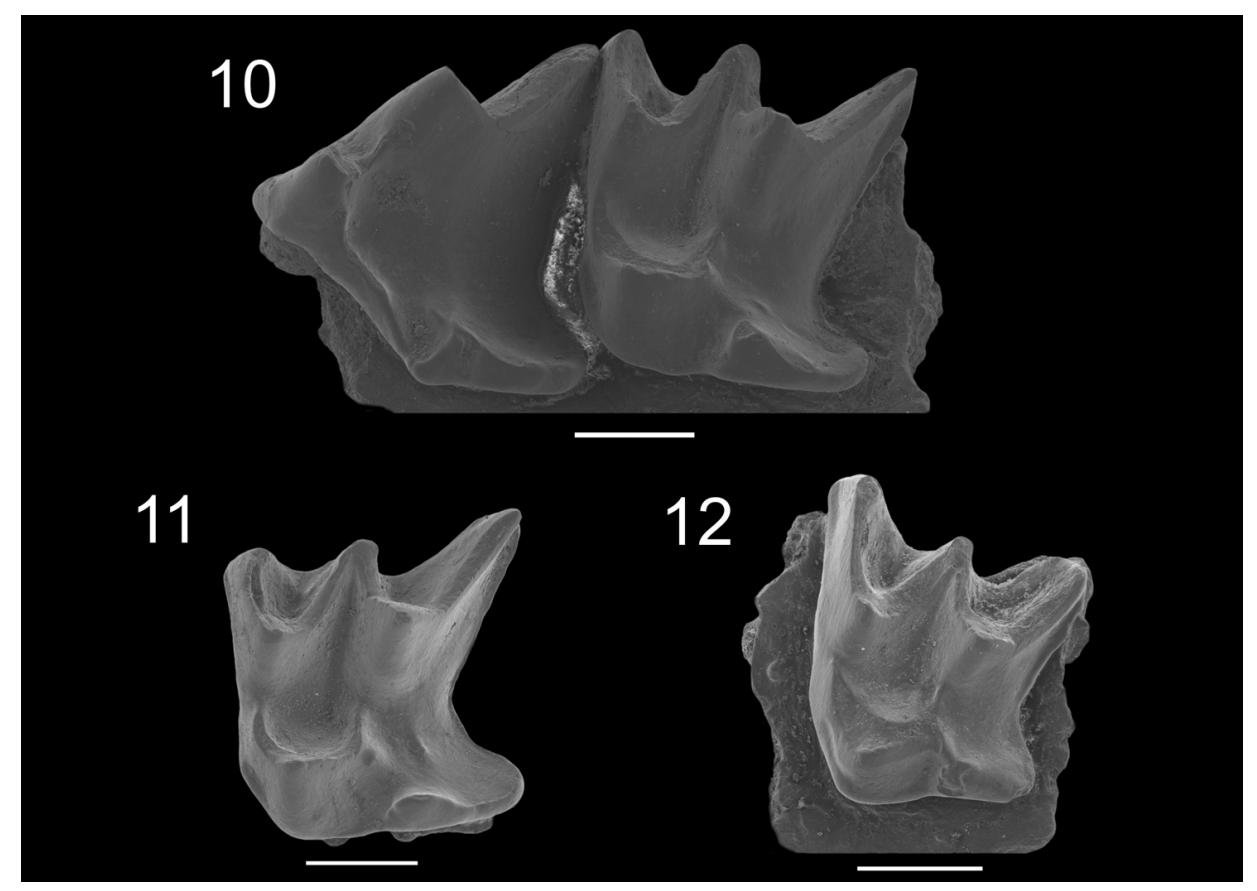

Figs 10-12. Beremendia fissidens (Petényi, 1864), Somssich Hill 2, scale bar: $1 \mathrm{~mm} .10=$ left maxillary fragment with $\mathrm{P}^{4}-\mathrm{M}^{1}$, layer 32 , occlusal view, $11=$ right $\mathrm{M}^{1}$, layer 28 , occlusal view, $12=$ left maxillary fragment with $\mathrm{M}^{2}$, layer 31 , occlusal view 
spicule is thin, poorly developed and nearly vertical. The condyloid process is characteristic. The angular process is very short (Figs 3-6).

Dentition - $\mathrm{I}^{1}$ is fissident with a bifid apex. The lingual part of $\mathrm{P}^{4}$ crown is very low. The occlusal outline is nearly triangular but it can be variable. The occlusal outline of $\mathrm{M}^{1}$ is square with rounded corners. By comparison, $\mathrm{M}^{2}$ has a more developed parastyle which protrudes buccally beyond the mesostyle and the metastyle. $\mathrm{M}^{3}$ was not found in the studied material. The crown and the root of $\mathrm{I}_{1}$ are equally stout and elongated. The crown of the lower incisor is grooved and acuspulate. $M_{1}$ and $\mathrm{M}_{2}$ have trapezoidal outlines in occlusal view; the trigonid basins are deep and broad. $\mathrm{M}_{3}$ is reduced but its talonid is basined (Figs 2, 6-12, 16).

Differential diagnosis (according to present study on the material of the Somssich Hill 2 and Osztramos 7 localities): B. fissidens differs from B. minor not only in size but there are also some different morphological characters. These are the following: $\mathrm{I}^{1}$ - the angle between the ventral part of the apex and the anterior margin of the talon is different; $\mathrm{I}_{1}-$ B. fissidens has a less pointed apex and has a less curved lower incisor; $\mathrm{M}_{3}-B$. fissidens has a low entoconid, a straight hypolophid and the posterior margin of the talonid is angular. Contrarily, B. minor has a high entoconid, a rounded hypolophid and the posterior margin of the talonid is round (Figs $7-8,15$ ).

Remarks - According to our observations B. fissidens specimens from Osztramos 7 site (MN 16) have four upper antemolars being situated in one line. $B$. fissidens remains from Somssich Hill 2 locality (late Early Pleistocene) have four upper antemolars as well but the fourth is situated more lingually, hidden beside $\mathrm{P}^{4}$. Four antemolars are not characteristic at all for Beremendia species, for example the East Asian B. jiangnanensis Jin et al., 2009 usually has three upper antemolars (JiN et al. 2009). Reduction of the number of the upper antemolars could be an evolutional trend in the tribe.

\section{Beremendia minor Rzebik-Kowalska, 1976}

(Figs 13-15)

1962 Beremendia fissidens (Petényi) - DeHM, pp. 25-26, pl. 3, figs 10-13.

1964 Beremendia sp. - FeJFAR, pp. 33-34.

1976 Beremendia minor n. sp. - RZEBI K-KowALSKA, pp. 369-371, tabs IV-V, figs 12-16, 17a, 18c. 1984 Beremendia minor Rzebik-Kowalska - ReUmer, p. 101, text-fig. 16, pl. 32, figs 14-15, pl. 33 , figs 7-9, pl. 35, figs 3-6.

1996 Beremendia minor Rzebik-Kowalska - Dahlmann \& STORCH, p. 185.

2009 Beremendia minor Rzebik-Kowalska - Rofes \& CuenCA-Bescos, pp. 30-32, fig. 5.

2013 Beremendia minor Rzebik-Kowalska - RzEBIK-Kowals KA, pp. 26, 28.

Type material - Holotype: right mandible fragment with $\mathrm{P}^{4}-\mathrm{M}^{3}$ and skull processes except angular process (ZZSiD, No. MF/1513). $\mathrm{I}^{1}$, left and right maxil- 
lary fragment with $\mathrm{M}^{1}$ and $\mathrm{M}^{2}$, left mandible fragment with $\mathrm{M}_{1}$ and skull processes except the angular process, and 9 right mandible fragments, partly with skull processes except the angular process and all together providing a full set of the lower teeth except I (RzEBIK-KowALSKA 1976).

Type locality - Rębielice Królewskie 1A, Poland, Upper Pliocene (MN 16, Lower Villafranchian Stage).

Studied material - Somssich Hill 2 locality: 1 right maxillary fragment, 1 left mandible fragment, 5 right mandible fragments, 1 right $\mathrm{P}^{4}, 1$ left $\mathrm{M}^{1}, 1$ right $I_{1}$ and 1 right $M_{2}$.

Measurements - Table 2.

Dental formula - 153/123.

Original diagnosis - The morphological structure of $B$. minor is an exact counterpart of the structure of $B$. fissidens, in connection with which its classification in the genus Beremendia does not rouse doubt. However, the dimensions of this species are much smaller than those of the members of $B$. fissidens from the same locality and the smallest specimens from the Pliocene locality at Węże I. As the difference in size is conspicuous, the dimensions of the two forms do not overlap, and they occur in the same locality, the small form has been included in a separate species (after RZEBIK-KowALSKA 1976).

Emended diagnosis - According to REUMER (1984) B. minor is morphologically identical to $B$. fissidens. The two species differ only in size, $B$. minor is considerably smaller than $B$. fissidens.

Table 2. Measurements of Beremendia minor teeth from Somssich Hill 2 (for the abbreviations see "Material and methods")

\begin{tabular}{llccccc}
\hline & & $\mathrm{n}(\mathrm{pcs})$ & min. $(\mathrm{mm})$ & mean $(\mathrm{mm})$ & $\max .(\mathrm{mm})$ & $\mathrm{SD}(\mathrm{mm})$ \\
\hline $\mathrm{M}^{1}$ & $\mathrm{LL}$ & 1 & - & 1.87 & - & - \\
& $\mathrm{BL}$ & 1 & - & 2.00 & - & - \\
& $\mathrm{AW}$ & 1 & - & 2.07 & - & - \\
& $\mathrm{PW}$ & 1 & - & 1.87 & - & - \\
\hline $\mathrm{M}^{2}$ & $\mathrm{LL}$ & 1 & - & 1.47 & - & - \\
\hline $\mathrm{I}_{1}$ & $\mathrm{~L}$ & 1 & - & 5.93 & - & - \\
& $\mathrm{H}$ & 1 & - & 2.13 & - & - \\
\hline $\mathrm{M}_{1}$ & $\mathrm{~L}$ & 3 & 2.33 & 2.44 & 2.60 & 0.1388 \\
& $\mathrm{~W}$ & 3 & 1.13 & 1.31 & 1.40 & 0.1540 \\
\hline $\mathrm{M}_{2}$ & $\mathrm{~L}$ & 6 & 1.80 & 1.90 & 2.07 & 0.1022 \\
& W & 6 & 1.07 & 1.16 & 1.33 & 0.1089 \\
\hline $\mathrm{M}_{3}$ & $\mathrm{~L}$ & 2 & 1.33 & 1.33 & 1.33 & 0.0024 \\
& $\mathrm{~W}$ & 2 & 0.80 & 0.84 & 0.87 & 0.0495 \\
\hline
\end{tabular}




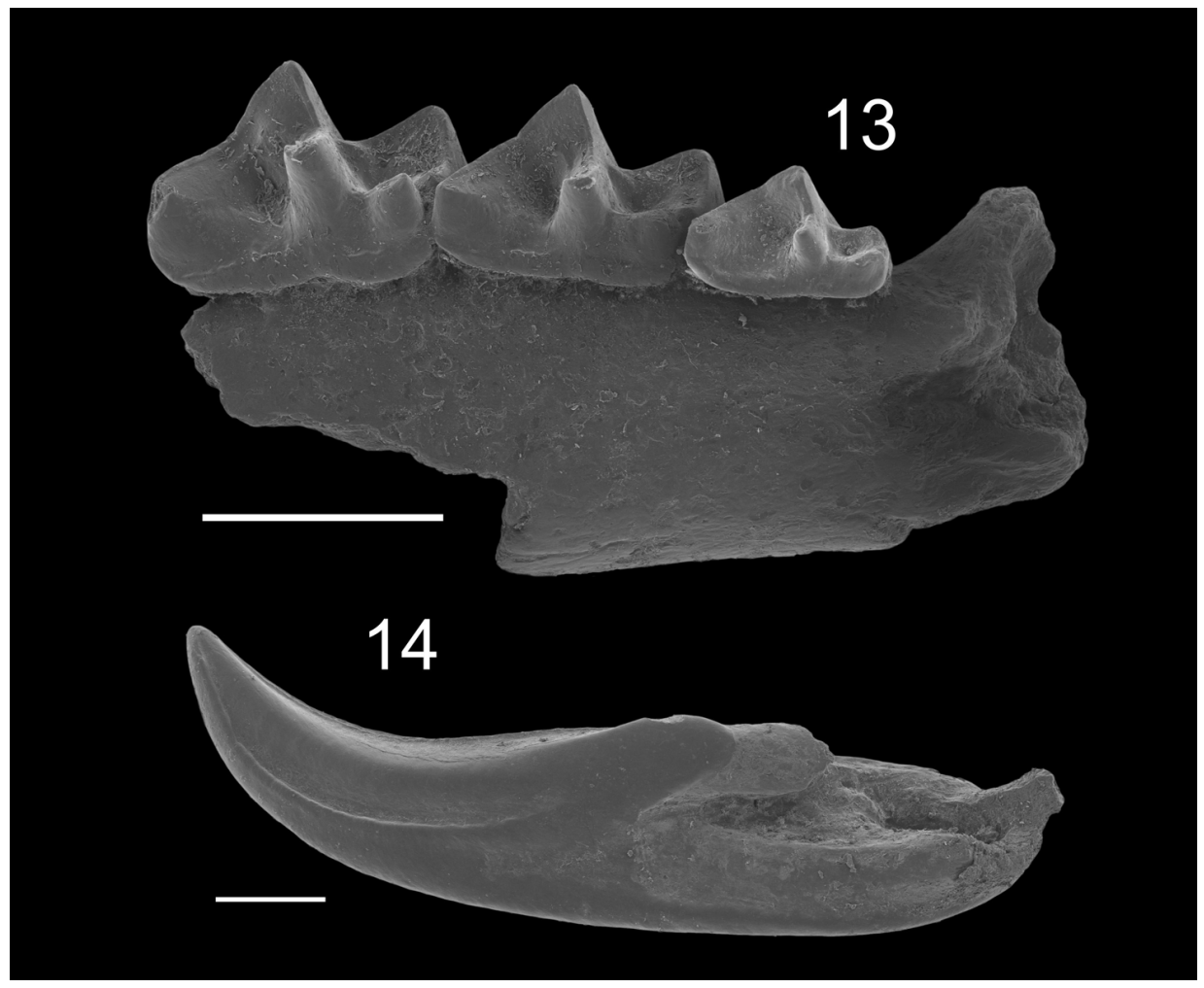

Figs 13-14. Beremendia minor Rzebik-Kowalska, 1976, Somssich Hill 2. 13 = right mandible fragment with $M_{1}-M_{3}$, layer 35, lingual view, scale bar: $2 \mathrm{~mm}, 14=$ right $I_{1}$, layer 14, medial view, scale bar: $1 \mathrm{~mm}$

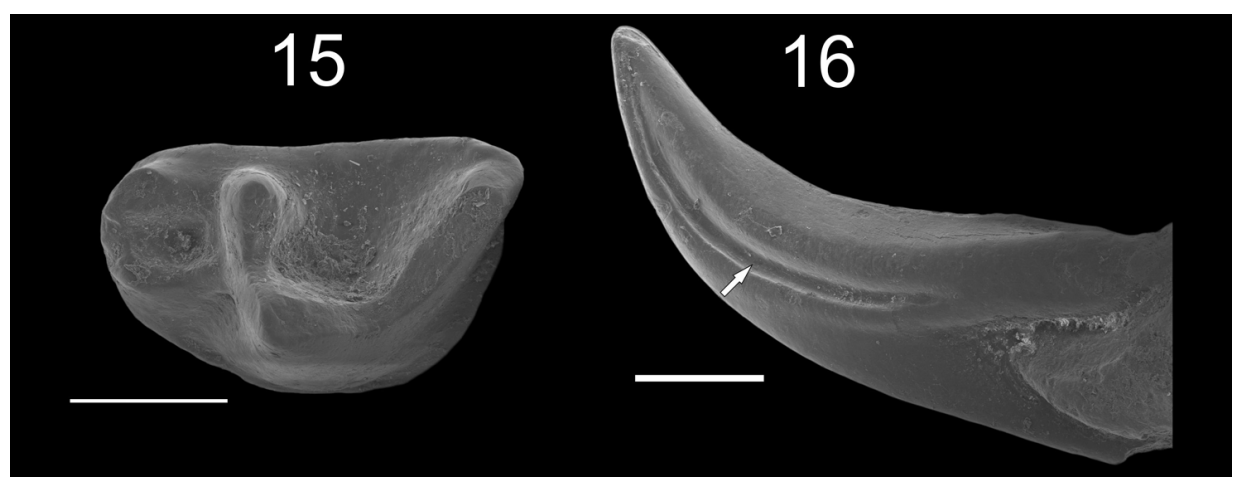

Figs 15-16. Beremendia fissidens (Petényi, 1864) and Beremendia minor Rzebik-Kowalska, 1976, Somssich Hill 2, scale bar: $0.5 \mathrm{~mm} .15=B$. minor right $\mathrm{M}_{3}$, layer 35 , occlusal view, $16=B$. fissidens right $\mathrm{I}_{1}$, layer 13 , medial view, the venom groove is marked by the white arrow 
Anatomical description - The dimensions of the species are significantly smaller than those of $B$. fissidens (not only the dental elements but also the size of the mental foramen, its anterior basin and the parameters of the symphysis fossa). $I^{1}$ - The angle of $I^{1}$ is smaller between the ventral part of the apex and the anterior margin of the talon. $\mathrm{I}_{1}$ - It has a more pointed apex and a more curved lower incisor. $\mathrm{M}_{3}-$ B. minor has a high entoconid, a rounded hypolophid and the posterior margin of the talonid is round (Figs 13-15).

Remarks - The occurrence of the small form of Beremendia is also mentioned by FEJFAR (1964) from Hajnačka (Slovakia), which corresponds in age with Rębielice Królewskie. Fejfar described them as Beremendia sp. According to Rzebik-Kowalska (1976) Beremendia fissidens remains from Schernfeld (Austria) (Deнm 1962) and the Beremendia sp. from Hajnačka (Fejfar 1964) seems to be as small as $B$. minor in dimensions. The measurements of the small form of Beremendia from the Somssich Hill 2 locality compounds with the aforementioned remains (DEHM 1962; FEJFAR 1964).

\section{CONCLUSIONS}

Taxonomy

The bigger $B$. fissidens and the smaller $B$. minor are well distinguished by the size of the upper and lower molars (Figs 17-20). The separation is supported by the morphometrical analysis made on the $\mathrm{M}_{2}$ length and width of the two forms.

We used $P$-values of the Shapiro-Wilk normality test to demonstrate the separation of the two Beremendia species (SHAPIRO \& WilK 1965; RAZALI \& WAH

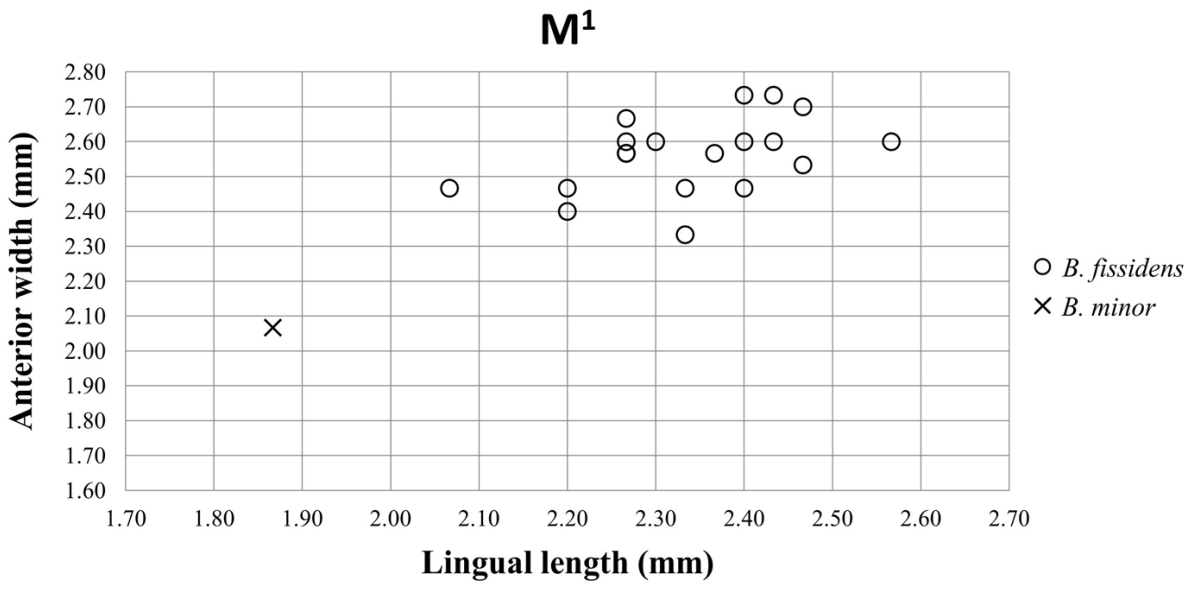

Fig. 17. Measurements of the $M^{1}$ teeth of $B$. fissidens and B. minor specimens 


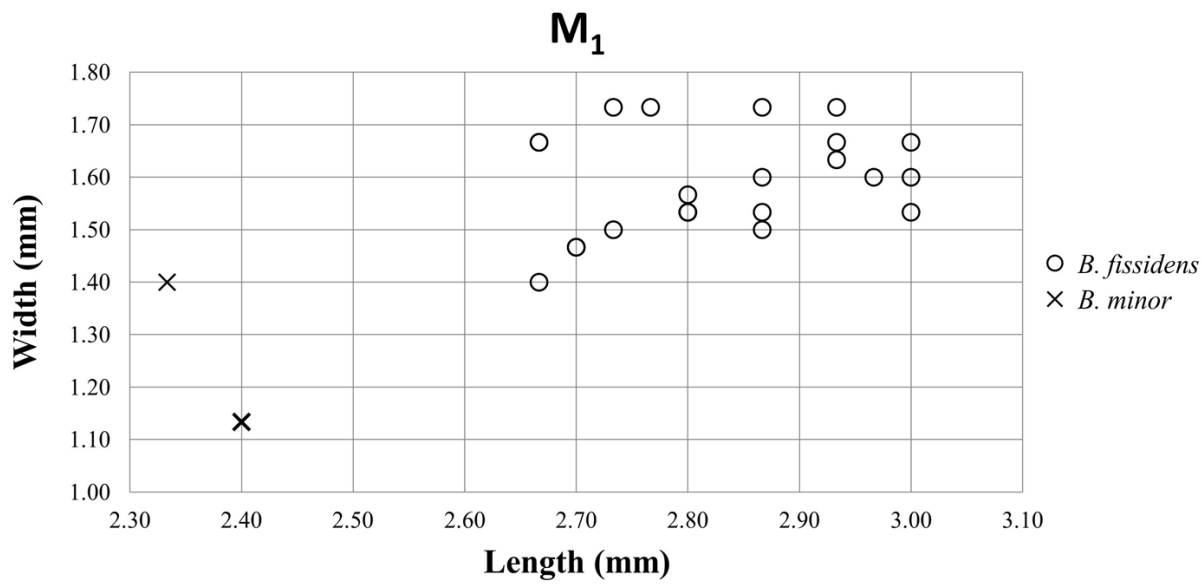

Fig. 18. Measurements of the $M_{1}$ teeth of $B$. fissidens and B. minor specimens

2011). $P$-value above 0.05 shows a normal distribution which indicates the presence of only one species (in case of 95\% confidence interval) (Goodman 2008). In the case of the common set of the measurement data of B. fissidens and B. minor do not show normal distribution, indicating the presence of different species ( $P$-value of length: $0.0026, P$-value of width: 0.0017$)$. Contrarily, $P$-value of length is 0.0581 , $P$-value of width is 0.1017 at $B$. fissidens, while $P$-value of length is $0.1165, P$-value of width is 0.0460 at $B$. minor (because of the few data it is plausible). The measurements of the two different species show normal distribution if we divide them.

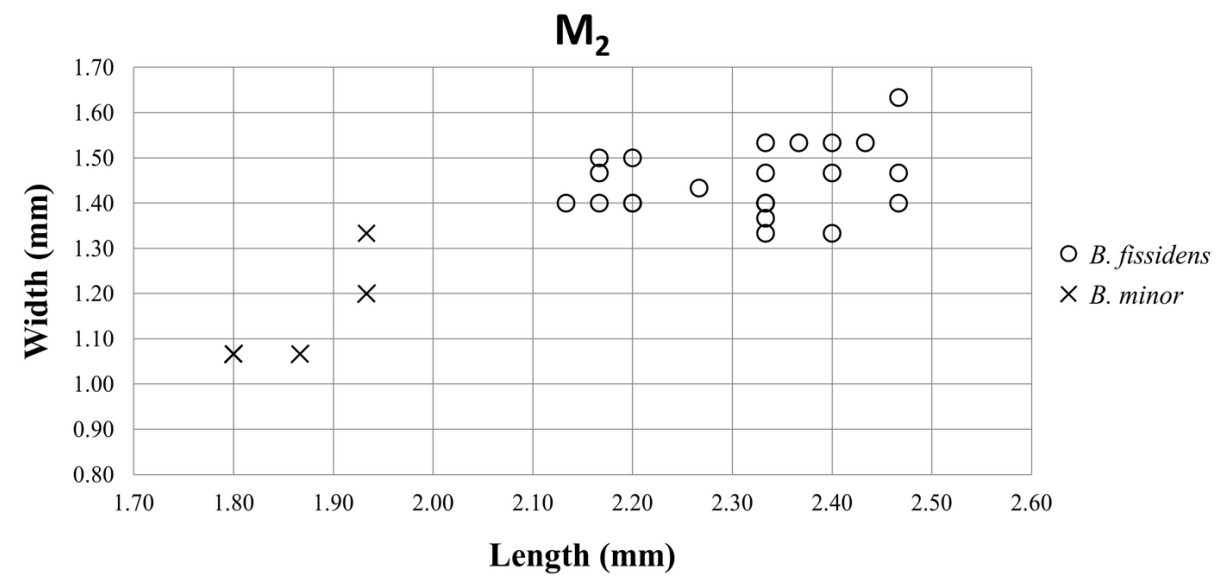

Fig. 19. Measurements of the $\mathrm{M}_{2}$ teeth of B. fissidens and B. minor specimens 
The linear correlation (Fig. 21), the box plots (Fig. 22), the regression lines (Fig. 23) and the confidence ellipses (Fig. 24) show that the measurement data of Somssich Hill $2 B$. fissidens and B. minor specimens constitute two significantly different sets (confidence interval 95\%).

Making a comparison between the Hungarian Beremendia specimens and the older Polish ones (after Fejfar 1964 and Rzebik-Kowalska 1976) shows that the detachment of the two forms became more expressive to the end of the Early Pleistocene (Fig. 25). The difference was caused by the size growth of $B$. fissidens while the measurements of $B$. minor did not develop significantly. This divergent progression could be the main evolutionary trend after the specific separation.

Some details in the dental morphology (the form of the upper and lower incisors), the size of the mental foramen and its anterior basin, the parameters of the sympysis fossa also prove them to be different taxa.

The main differential characters are present on $\mathrm{M}_{3}$ talonid, which were similarly found not only here, but on the specimens of the North Hungarian Pliocene Osztramos 7 (MN 16) site as well.

Sum up, the main differential characters between B. fissidens and B. minor specimens from the Somssich Hill 2 locality are as follows: $B$. fissidens is bigger (mainly in the length of the lower molars). It has basined $\mathrm{M}_{3}$ talonid with straight posterior margin (hypolophid) and the entoconid is lower than that one of the smaller species. Contrarily, B. minor has a more reduced, not basined $\mathrm{M}_{3}$ talonid with rounded posterior margin and with high entoconid (Figs 7-8, 13, 15, 17-25).

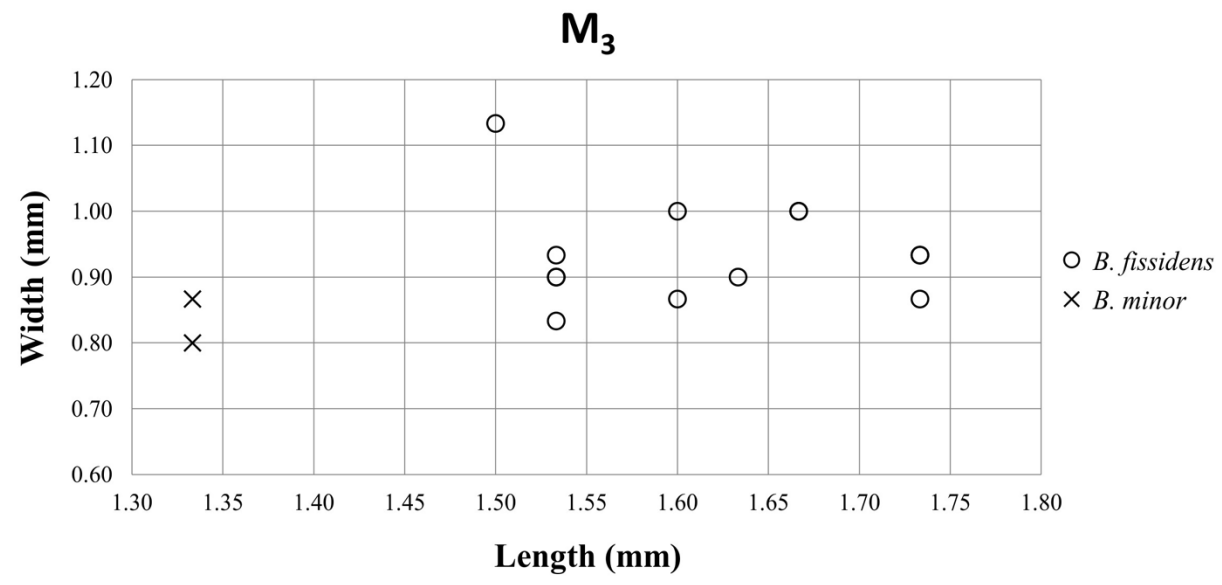

Fig. 20. Measurements of the $\mathrm{M}_{3}$ teeth of $B$. fissidens and $B$. minor specimens 


\section{Biostratigraphy}

The estimated age of Somssich Hill 2 locality is approximately 800-900 ka (Mimomys savini-M. pusillus biozone by Kordos 1994) on the basis of the vole fauna (Pazonyi et al. 2013a, $b$; Pazonyi \& Virág 2013a, b) (Fig. 26). The identified shrew and dormouse fauna (Sorex, Crocidura, Beremendia, Glis, Muscardinus and Dryomimus species) confirmed this hypothesis (ВоTKA \& STRICZKY 2014; BOTKA \& MÉszÁros 2014).

B. fissidens is present from the MN14 zone (Osztramos 1, Podlesice, Zalesiaki 1B and Zamkowa Dolna Cave B) to the Tarkö Phase (ca. 350 ka) of the Middle Pleistocene (Tarkő) in Europe (Reumer 1984; StefaniaK et al. 2009; JÁnossy 1986) (Figs 27-29). The presence of B. minor in the studied material was surprising because this species was only found at Pliocene localities e.g. Rębielice Królewskie 1A (MN16), Osztramos 1 (MN14), Osztramos 7 (MN16), Hajnačka (MN16), Ivanovce (MN15) and Gundersheim-Findling (MN15) (RzEBIK-Ko-

B. fissidens \& B. minor

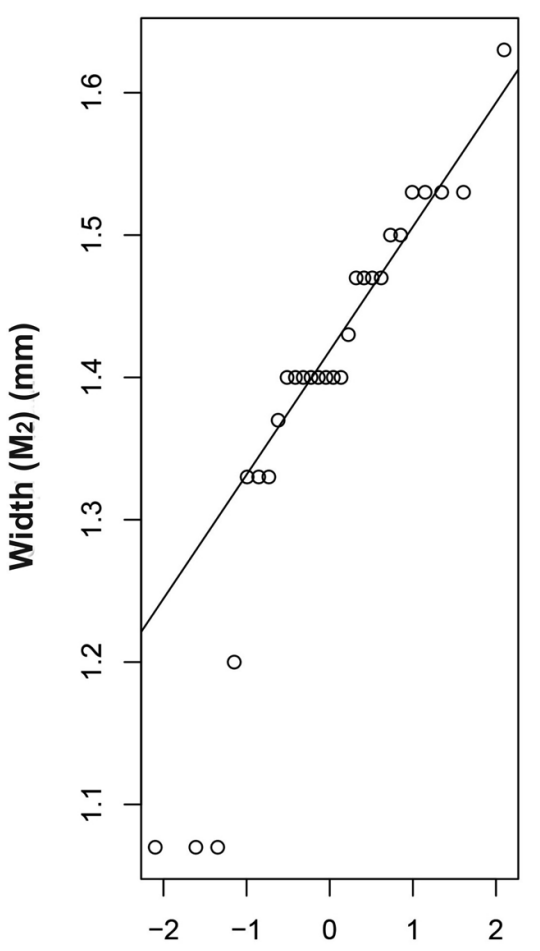

B. fissidens

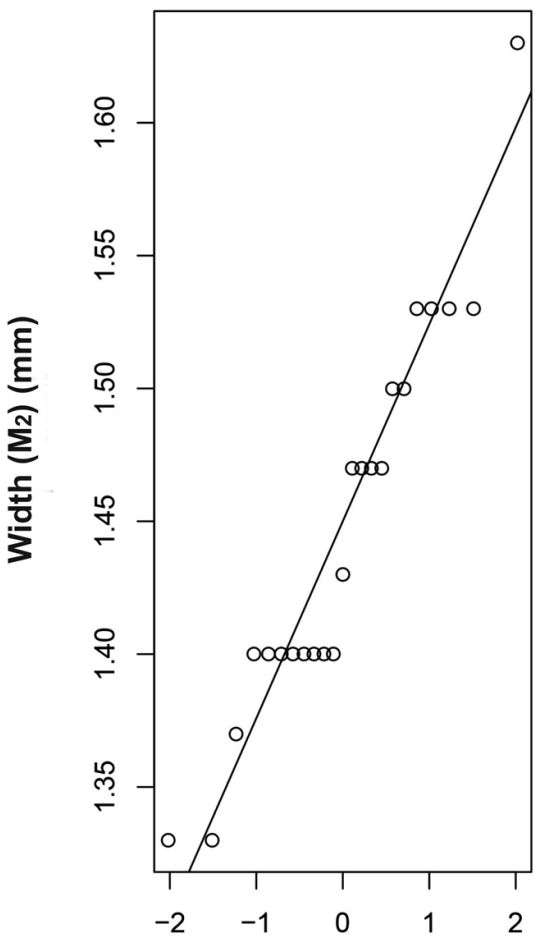

Fig. 21. Linear correlation of the Somssich Hill 2 Beremendia $\mathrm{M}_{2}$ measurements (confidence interval 95\%) 

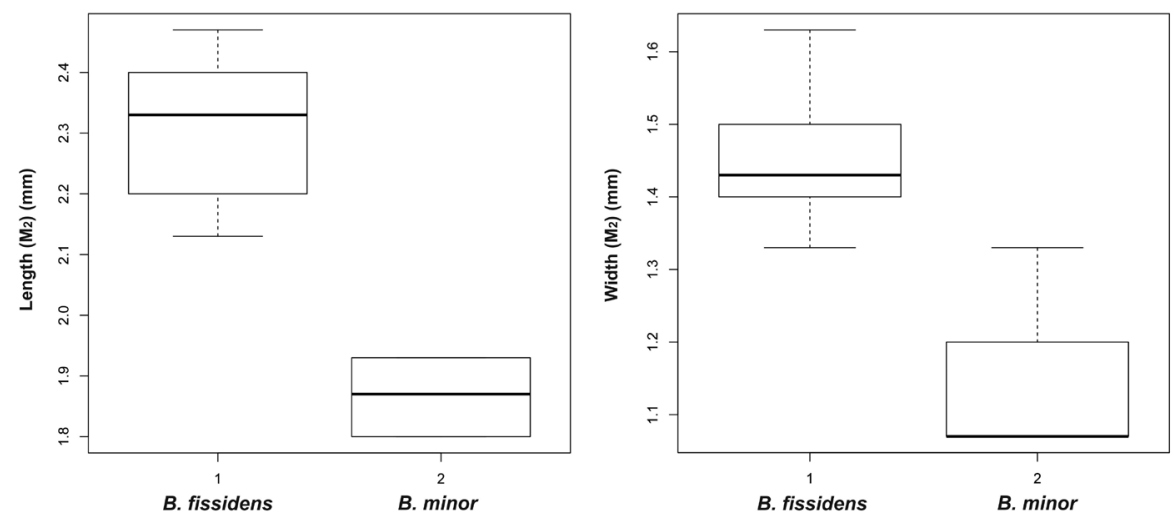

Fig. 22. Box plot of the separation of the Somssich Hill 2 Beremendia $\mathrm{M}_{2}$ measurements (confidence interval 95\%)

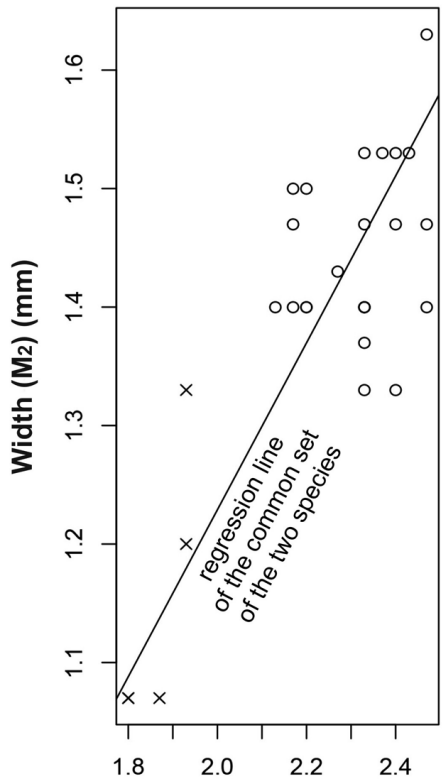

Length $\left(\mathrm{M}_{2}\right)(\mathrm{mm})$

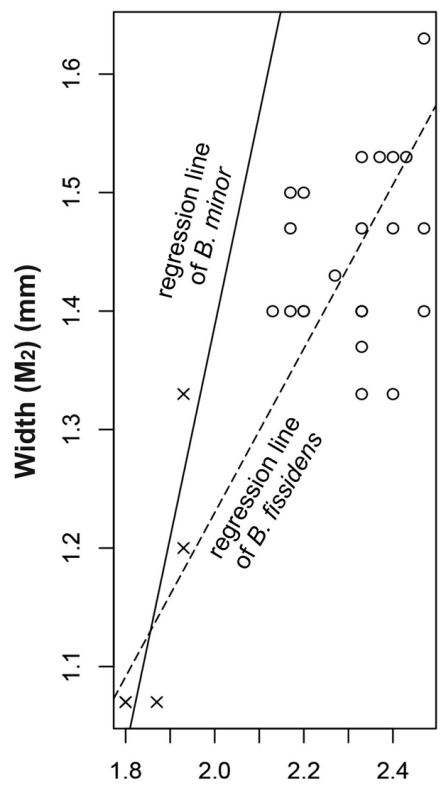

Length $\left(\mathrm{M}_{2}\right)(\mathrm{mm})$

measurements of $B$. fissidens
$\mathbf{X}$ measurements of $B$. minor

Fig. 23. Regression lines of the Somssich Hill 2 B. fissidens and B. minor $\mathrm{M}_{2}$ measurements. The linear equations: $\mathrm{y}$ (the common set of the two Beremendia species) $=0.5678 \mathrm{x}+0.1254, \mathrm{y}($ B. fissidens) $=0.1770 \mathrm{x}+1.0377, \mathrm{y}($ B. minor $)=1.4752 \mathrm{x}-1.6047$ 


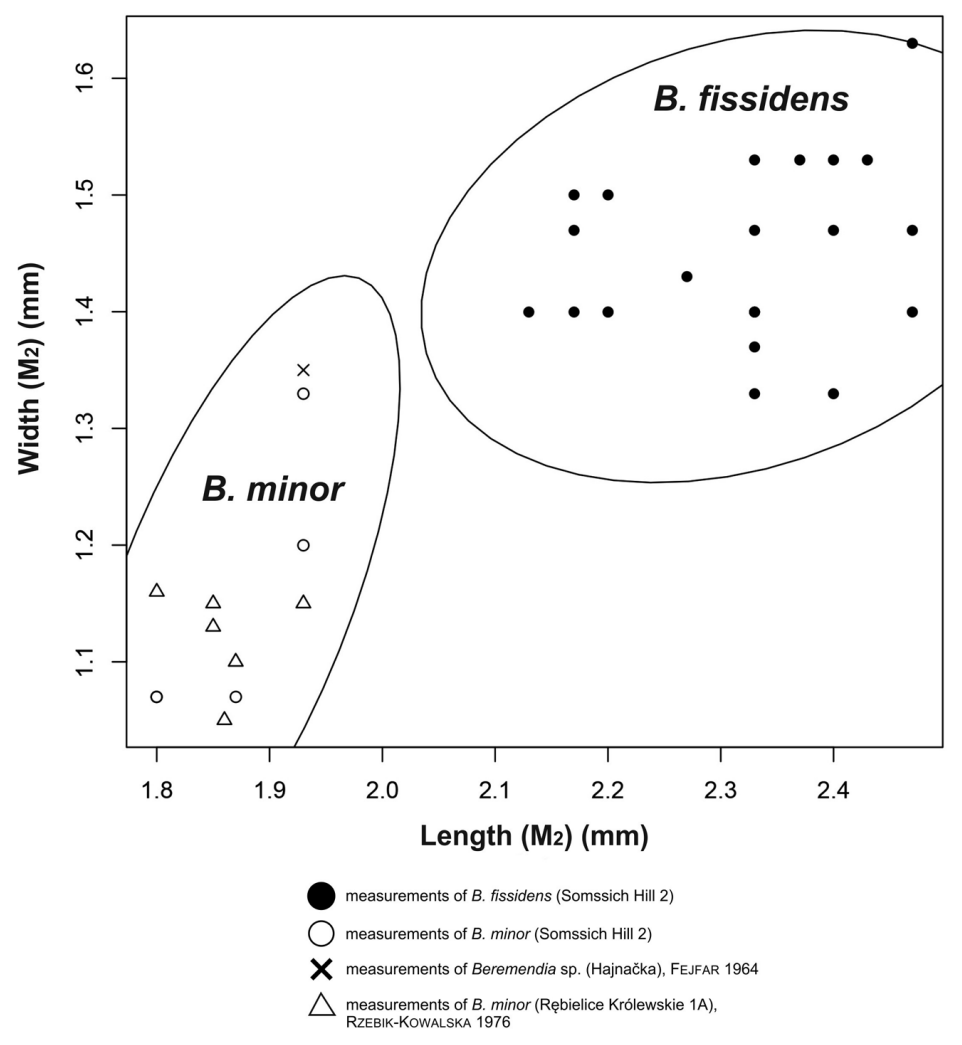

Fig. 24. Confidence ellipses of the Somssich Hill 2 B. fissidens and B. minor $\mathrm{M}_{2}$ measurements (confidence interval 95\%)

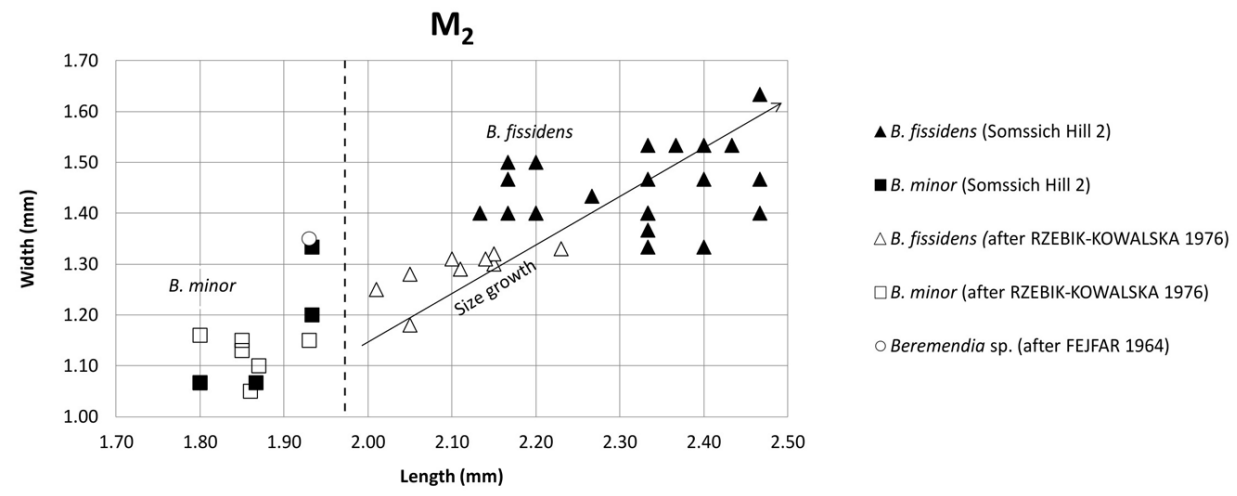

Fig. 25. Comparison between the Hungarian Beremendia specimens and the older Polish ones 


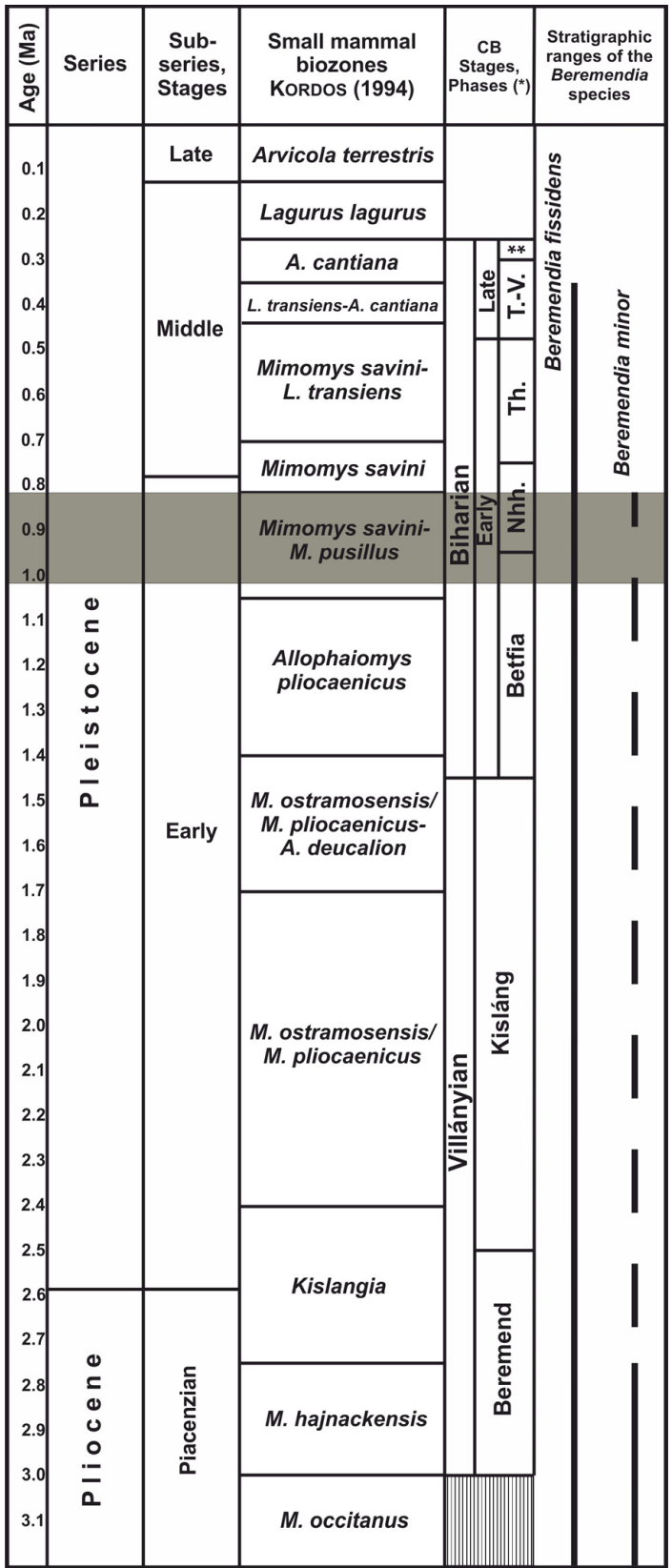

Fig. 26. Stratigraphical position of the Somssich Hill 2 locality (after Kordos 1994, Kretzor 1969, Kretzoi \& PÉCSI 1982, PAZONYi et al. 2013a), with the stratigraphical range of the studied species (CB = Carpathian Basin, ${ }^{*}=$ after KRETzoI 1969, KretzoI \& PÉcsI 1982, Nhh. = Nagyharsányhegy Phase, Th. $=$ Templomhegy Phase, T.-V. $=$ Tarkő-Vértesszőlős Phase and ${ }^{* *}=$ Uppony Phase) 

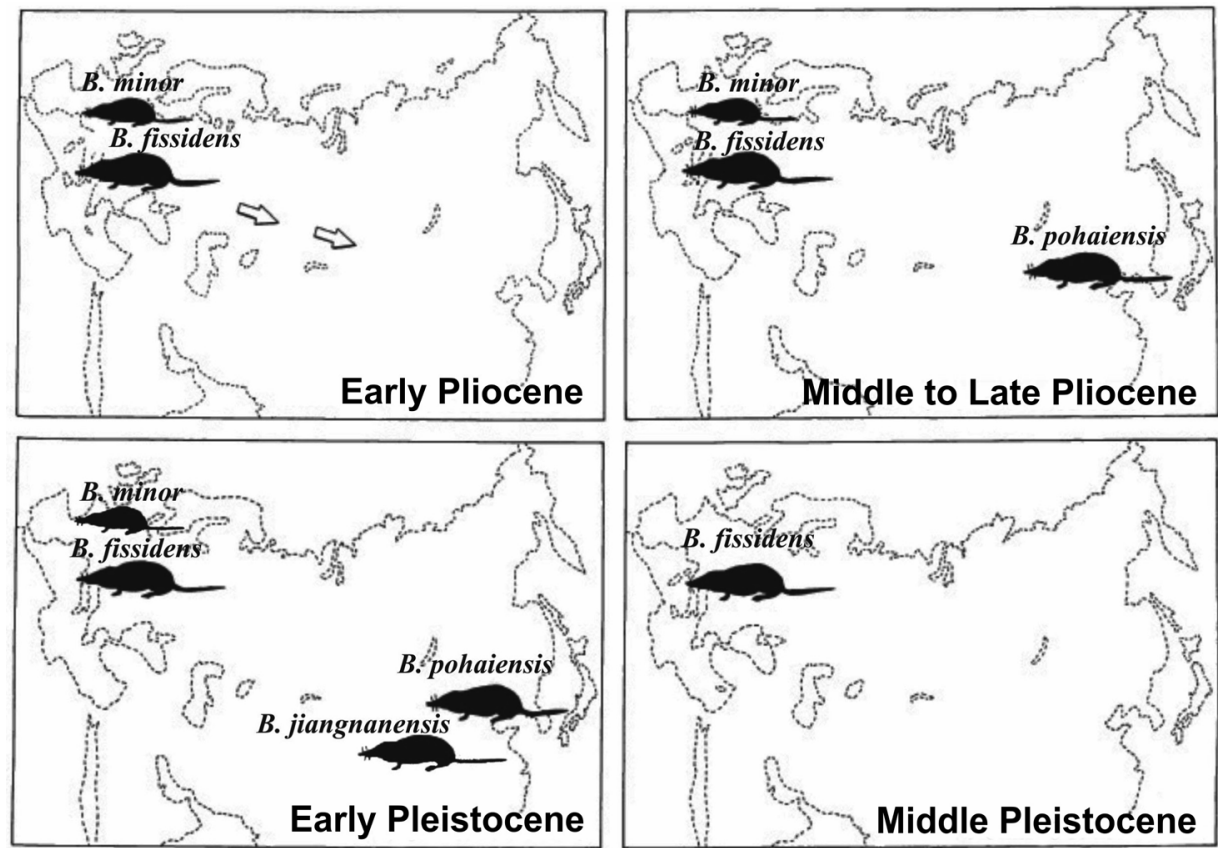

Fig. 27. Distribution of the genus Beremendia in Eurasia during the Plio-Pleistocene (modified after Jin \& KAWAMURA 1996)

\begin{tabular}{|c|c|c|}
\hline COUNTRY & FAD (First Appearance Datum) & LAD (Last Appearance Datum) \\
\hline Poland & Early Pliocene (MN 14) & Middle Pleistocene \\
\hline Hungary & Early Pliocene (MN 14) & Middle Pleistocene \\
\hline Switzerland & Middle Pliocene (MN 15) & Middle Pliocene (MN 15) \\
\hline Austria & Middle Pliocene (MN 15) & Late Pliocene (MN 16) \\
\hline Slovenia & Middle Pliocene (MN 15) & Early Pleistocene (MN 17) \\
\hline Greece & Middle Pliocene (MN 15) & Early Pleistocene (QM 01) \\
\hline Slovakia & Middle Pliocene (MN 15) & Early Pleistocene (QM 01) \\
\hline Czech Republic & Middle Pliocene (MN 15) & Early Pleistocene (QM 01) \\
\hline Germany & Middle Pliocene (MN 15) & Middle Pleistocene \\
\hline Romania & Middle Pliocene (MN 15) & Middle Pleistocene \\
\hline Spain & Late Pliocene (MN 16) & Early Pleistocene (QM 01) \\
\hline Italy & Late Pliocene (MN 16) & Middle Pleistocene \\
\hline the Netherlands & Early Pleistocene (MN 17) & Early Pleistocene (MN 17) \\
\hline Bulgaria & Early Pleistocene (MN 17) & Early Pleistocene (MN 17) \\
\hline England & Early Pleistocene (MN 17) & Middle Pleistocene \\
\hline France & Early Pleistocene (MN 17) & Middle Pleistocene \\
\hline Croatia & Early Pleistocene (QM 01) & Early Pleistocene (QM 01) \\
\hline Georgia & Early Pleistocene (QM 01) & Early Pleistocene (QM 01) \\
\hline Ukraine & Early Pleistocene (QM 01) & Middle Pleistocene \\
\hline Russia & Early Pleistocene (QM 01) & Middle Pleistocene \\
\hline
\end{tabular}

Fig. 28. First (FAD) and last (LAD) appearance data of the genus Beremendia in the European countries 
WAlska 1976, 2013; Reumer 1984; Fejfar 1964; Dahlmann \& STorch 1996) by this time. According to RzEBIK-KowalskA (2013) it is likely that for some reason $B$. minor is rarely found in fossil materials because it is similar to some other more frequent taxa e.g. Paenelimnoecus or Neomys.

According to our data, B. minor is present in the Early Pleistocene of Hungary; therefore, the stratigraphical range of this species could have been extended (with ca. further 2 million years) (Fig. 26).

\section{Palaeoecology}

Today B. fissidens is said in the references to had been venomous. This hypothesis is induced by its specially adapted, first lower incisor on which there is a well-marked "venom groove" running along the medial side of its crown (Fig. 16).

FURIó et al. (2010) analyzed the anatomical characters of Beremendia. Examining its dental characters, they do reassess the venomous nature of the

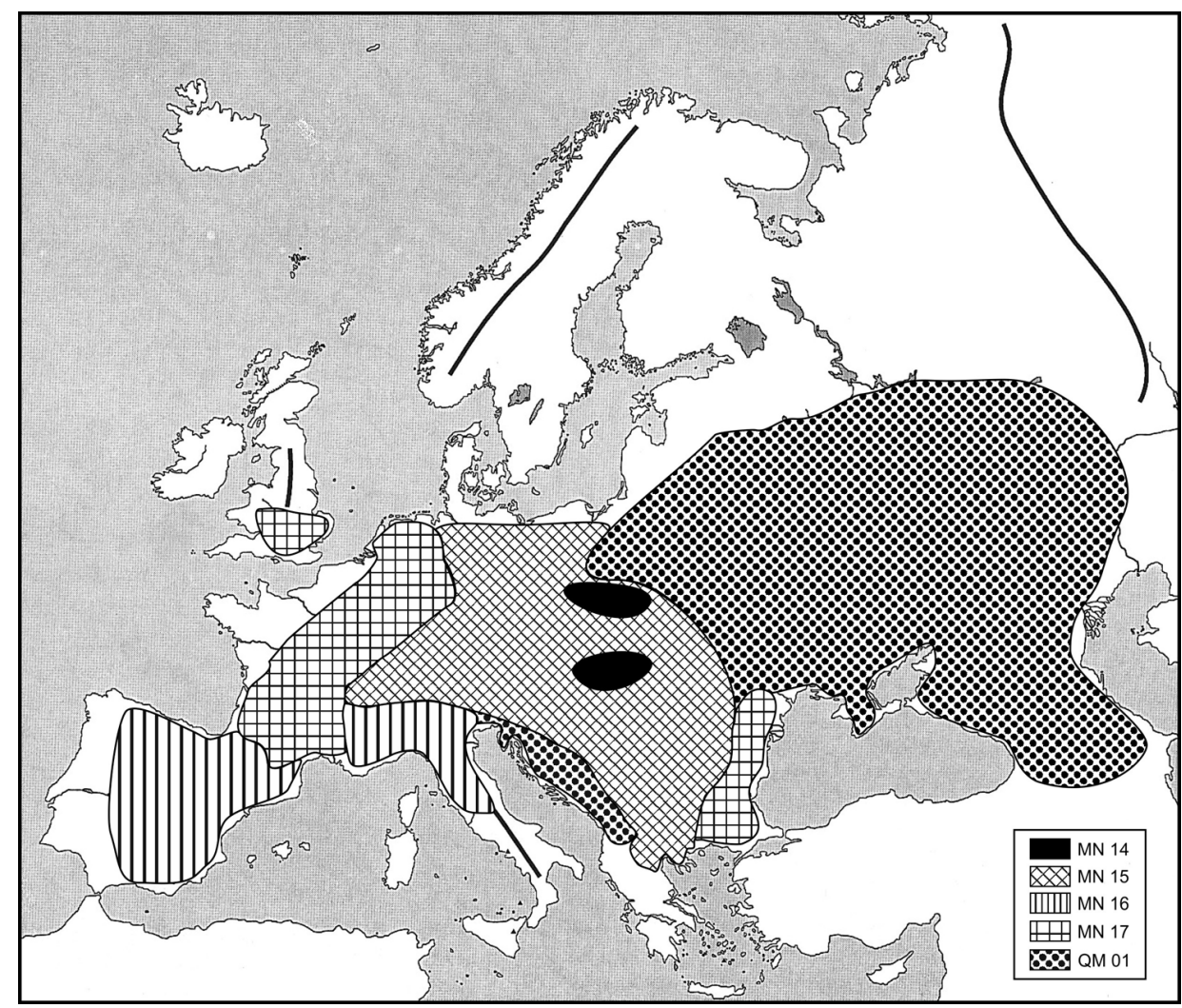

Fig. 29. Occurrence of the genus Beremendia in Europe on the basis of the FADs. The marked areas show the maximal distribution of the genus in the given time interval 
species included in this genus and they deduce that the diet of Beremendia was highly specialized in coleopterans and gastropods. According to them, the use of venom in shrews feeding on non-struggling prey can be reliably explained as a mechanism to subdue the prey without killing them before the real time of consumption. The induction of victims into a comatose-state permits their hoarding for a longer time in a better state of preservation than if they were dead, thus diminishing the risk of starvation (LIGABUE-BRAUN et al. 2012). Such strategy provides important benefits to their users under unpredictable conditions, because the effects of environmental unpredictability are consequently reduced.

BENNÁSAR et al. (2014) have found taphonomical evidences that $B$. fissidens may have had the capacity to bite prey larger than itself (small mammals, e.g. moles). The addition of small vertebrates to complement a diet based on insects and snails could have been a way of responding to the needs of the high metabolic rate characteristic of the giant shrews.

\begin{tabular}{|c|c|c|c|c|c|c|c|}
\hline \multicolumn{8}{|c|}{ The stratigraphic range of the genus Beremendia in Europe } \\
\hline & \multicolumn{3}{|c|}{ PLIOCENE } & \multicolumn{3}{|c|}{ PLEISTOCENE } & \multirow{2}{*}{$\begin{array}{c}\text { REFERENCES } \\
\text { AUTHORS (publication year) }\end{array}$} \\
\hline & MN 14 & MN 15 & MN 16 & MN 17 & Early & Middle & \\
\hline Romania: & & & & & & & RZEBIK-KOWALSKA (2005b) \\
\hline Dranič-0 & & $x$ & & & & & RZEBIK-KOWALSKA (2002) \\
\hline Podari 2 & & & $x$ & & & & RZEBIK-KOWALSKA (2002) \\
\hline Slatina 2 & & & & $x$ & & & RADULESCU \& SAMSON (2001) \\
\hline Izvoru 2 & & & & & $x$ & & RZEBIK-KOWALSKA (2002) \\
\hline Braşov & & & & & $\mathrm{x}$ & & RADULESCU \& KISGYÖRGY (1970) \\
\hline Ursilor Cave (Chiscau) & & & & & $x$ & $x$ & TERZEA (1983) \\
\hline Betfia $2,5,7,9,10,11,13$ & & & & & $x$ & $x$ & TERZEA (1973), RZEBIK-KOWALSKA (2000) \\
\hline Gesprengberg Cave & & & & & & $x$ & TERZEA (1983) \\
\hline Greece: & & & & & & & DOUKAS (2005) \\
\hline Ptolemais lignite mines & & $\mathrm{x}$ & & & & & VAN DE WEERD (1979) \\
\hline Tourkobounia 1 & & & $x$ & & & & REUMER \& DOUKAS (1985) \\
\hline Voulgarakis & & & & & $x$ & & KOUFOS (2001) \\
\hline Marathoussa & & & & & $x$ & & KOUFOS (2001) \\
\hline Switzerland: & & & & & & & ENGESSER (2005) \\
\hline Vue-des-Alpes & & $\mathrm{x}$ & & & & & BOLLIGER et al. (1993) \\
\hline Slovakia: & & & & & & & FEJFAR \& SABOL (2005) \\
\hline Ivanovce & & $\mathrm{x}$ & & & & & FEJFAR \& SABOL (2004) \\
\hline Hostovce 2 & & $\mathrm{x}$ & $\mathrm{x}$ & & & & CERMAK et al. $(2007,2008)$ \\
\hline Hajnačka & & & $x$ & & & & FEJFAR (1964), FEJFAR \& SABOL (2004) \\
\hline Plešivec 1 & & & $x$ & & & & FEJFAR \& HORACEK (1983) \\
\hline Kolín̆any $1,2,3$ & & & & & $\mathrm{x}$ & & HORACEK \& LOZEK (1988) \\
\hline Včelare $3,4,5,6$ & & & & & $x$ & & HORACEK (1985) \\
\hline Gombasek 1,2 & & & & & $x$ & & KRETZOI (1941) \\
\hline the Netherlands: & & & & & & & REUMER (2005) \\
\hline Brielle 1 & & & & $\mathrm{x}$ & & & VAN DER MEULEN \& ZAGWIJN (1974) \\
\hline Oosterschelde & & & & $\mathrm{x}$ & & & REUMER et al. (2005) \\
\hline Tegelen & & & & $x$ & & & FREUDENTHAL et al. (1976), REUMER (1984) \\
\hline Zuurland & & & & $\mathrm{x}$ & & & REUMER \& HORDIJK (1999) \\
\hline Bulgaria: & & & & & & & RZEBIK-KOWALSKA \& POPOV (2005) \\
\hline Varshets & & & & $\mathrm{x}$ & & & POPOV (2003) \\
\hline
\end{tabular}

Fig. 30a. Summary about the stratigraphical range of the genus Beremendia in Europe. References contain the most important publications about the localities (Romania, Greece, Switzerland, Slovakia, the Netherlands and Bulgaria) 
B. fissidens is reported from ecotypes nearby open water bodies (lakes or rivers) by several authors (e.g. CUENCA-BESCós et al. 2005; FuRIó et al. 2010; AgUSTÍ et al. 2011; GARCIA et al. 2014). Its adaptation to watersides is supported

\begin{tabular}{|c|c|c|c|c|c|c|c|}
\hline \multicolumn{8}{|c|}{ The stratigraphic range of the genus Beremendia in Europe } \\
\hline & \multicolumn{3}{|c|}{ PLIOCENE } & \multicolumn{3}{|c|}{ PLEISTOCENE } & \multirow{2}{*}{$\begin{array}{c}\text { REFERENCES } \\
\text { AUTHORS (publication year) }\end{array}$} \\
\hline & MN 14 & MN 15 & MN 16 & MN 17 & Early & Middle & \\
\hline Poland: & & & & & & & RZEBIK-KOWALSKA (2005a) \\
\hline Podlesice & $x$ & & & & & & KOWALSKI (1990), RZEBIK-KOWALSKA $(1994,2005 a)$ \\
\hline Zalesiaki 1A,1B & $\mathrm{x}$ & & & & $x$ & $x$ & RZEBIK-KOWALSKA $(1976,1994)$ \\
\hline Zamkowa Dolna Cave A,B,C & $x$ & & & $x$ & $\mathrm{x}$ & & $\begin{array}{l}\text { RZEBIK-KOWALSKA (1976, 1994, 2009), KOWALSKI (1990), } \\
\text { STEFANIAK et al. (2009) }\end{array}$ \\
\hline Węże 1,2 & & $\mathrm{x}$ & $\mathrm{x}$ & & & & SULIMSKI $(1959,1962)$, RZEBIK-KOWALSKA (1994) \\
\hline Rębielice Królewskie 1A,2 & & & $\mathrm{x}$ & & & $x$ & RZEBIK-KOWALSKA $(1976,1994)$ \\
\hline Przymilowice $1 \mathrm{~B}, 2 \mathrm{~B}, 3 \mathrm{~A}, 3 \mathrm{~B}$ & & & & $\mathrm{x}$ & $x$ & & RZEBIK-KOWALSKA $(1994,2005 \mathrm{a}, 2009)$ \\
\hline Kadzielnia 1 & & & & $\mathrm{x}$ & $\mathrm{x}$ & & KOWALSKI (1958), RZEBIK-KOWALSKA $(1976,1994)$ \\
\hline Kielniki 3A, 3B & & & & $x$ & $x$ & & $\begin{array}{l}\text { KOWALSKI (1990), RZEBIK-KOWALSKA }(1976,1994,2005 \text { a } \\
\text { 2009) }\end{array}$ \\
\hline Kamyk & & & & & $\mathrm{x}$ & & KOWALSKI (1960) \\
\hline Żabia Cave A,B & & & & & $x$ & & $\begin{array}{l}\text { BOSÁK et al. (1982), RZEBIK-KOWALSKA }(1994,2009 \text {, } \\
\text { 2013) }\end{array}$ \\
\hline Kozi Grzbiet 2 & & & & & & $x$ & RZEBIK-KOWALSKA (1976), STEFANIAK et al. (2009) \\
\hline Spain: & & & & & & & VAN DEN HOEK OSTENDE \& FURIO (2005) \\
\hline Barranco del Monte 1 & & & $\mathrm{x}$ & & & & LAPLANA CONESA et al. (2004) \\
\hline Moreda 1 & & & $\mathrm{x}$ & & & & RUIZ-BUSTOS \& SESÉ (1985) \\
\hline Orrios 3 & & & $\mathrm{x}$ & & & & ADROVER (1986) \\
\hline Valdeganga 2 & & & $\mathrm{x}$ & & & & MEIN et al. (1978) \\
\hline Almenara-Casablanca 1 & & & & $\mathrm{x}$ & & & AGUSTI et al. (2011) \\
\hline Sima del Elefante & & & & & $x$ & & $\begin{array}{l}\text { ROFES \& CUENCA-BESCOS (2009), CUENCA-BESCOS et al. } \\
(2010,2013)\end{array}$ \\
\hline Gran Dolina (Atapuerca) & & & & & $x$ & & ANTONANZAS \& CUENCA-BESCOS (2002) \\
\hline Austria: & & & & & & & ZIEGLER \& DAXNER-HÖCK (2005) \\
\hline \begin{tabular}{|l|} 
Deutsch-Altenburg \\
$2 \mathrm{~A}, 2 \mathrm{C}, 4 \mathrm{~B}, 9,14,20,21,26,30 \mathrm{~A}$
\end{tabular} & & $x$ & & & & & FRANK \& RABEDER (1997) \\
\hline Stranzendorf & & $\mathrm{x}$ & $x$ & & & & FRANK \& RABEDER (1997) \\
\hline Germany: & & & & & & & ZIEGLER et al. (2005) \\
\hline Gundersheim-Findling & & $\mathrm{x}$ & & & & & $\begin{array}{l}\text { HELLER (1936), DAHLMANN \& STORCH (1996), } \\
\text { DAHLMANN (2001) }\end{array}$ \\
\hline Wölfersheim & & $x$ & & & & & TOBIEN (1977), DAHLMANN (2001) \\
\hline Sondershausen & & $\mathrm{x}$ & & & & & HELLMUND \& ZIEGLER (2012) \\
\hline Hambach 11 & & & $x$ & & & & MÖRS et al. (1998) \\
\hline Gundersheim fissure fillings & & & $x$ & $\mathrm{x}$ & $x$ & & HELLER (1936), DAHLMANN \& STORCH (1996) \\
\hline \begin{tabular}{|l|} 
Neuleiningen 11 \\
\end{tabular} & & & & $\mathrm{x}$ & & & MAUL (1996) \\
\hline Deinsdorf & & & & $x$ & & & HELLER (1963) \\
\hline Schernfeld & & & & & $x$ & & DEHM (1962), CARLS \& RABEDER (1988) \\
\hline Weißenburg 7 & & & & & $x$ & & KOENIGSWALD (1971) \\
\hline Sackdillinger Cave & & & & & $x$ & & HELLER $(1930,1956)$ \\
\hline Hohensülzen & & & & & $\mathrm{x}$ & $\mathrm{x}$ & TOBIEN (1980) \\
\hline \multicolumn{8}{|l|}{ Georgia: } \\
\hline Dmanisi & & & & & $x$ & & FURIO et al. (2010) \\
\hline \multicolumn{8}{|l|}{ England: } \\
\hline East Runton (Norfolk) & & & & $x$ & $x$ & & $\begin{array}{l}\text { STUART (1980), HARRISON et al. (2006), HARRISON \& } \\
\text { PARFITT (2009) }\end{array}$ \\
\hline Sugworth & & & & & & $x$ & STUART (1980) \\
\hline \multicolumn{8}{|l|}{ Italy: } \\
\hline Cascina Arondelli (Piedmont) & & & $\mathrm{x}$ & & & & KOTSAKIS et al. (2003) \\
\hline Rivoli Veronese & & & & $\mathrm{x}$ & & & FANFANI \& MASINI (1997) \\
\hline Monte La Mesa (Verona) & & & & & $x$ & & MARCHETTI et al. (2000) \\
\hline Soave Cava Sud (Verona) & & & & & $x$ & $x$ & MARCOLINI et al. (2013) \\
\hline Monte Peglia & & & & & & $x$ & MAUL et al. (1998) \\
\hline
\end{tabular}

Fig. 30b. Summary about the stratigraphical range of the genus Beremendia in Europe. References contain the most important publications about the localities (Poland, Spain, Austria, Germany, Georgia, England and Italy) 
here by simultaneous occurrence with water-preferring amphibians and reptiles in the Somssich Hill 2 assemblage (Szentesi 2013, 2014a, b). On the other hand, the rodent fauna (e.g. the abundance of the dormice) of the studied site indicates the presence of closed vegetation.

The layer-by-layer occurrences of the two studied Beremendia species in the Somssich Hill 2 section do not show significant differences between the preferences of the two forms (Table 3). That is why both of them can be considered here as the indicators of gallery forests or bushy vegetation on the side of a lake or a river.

\begin{tabular}{|c|c|c|c|c|c|c|c|}
\hline \multicolumn{8}{|c|}{ The stratigraphic range of the genus Beremendia in Europe } \\
\hline & \multicolumn{3}{|c|}{ PLIOCENE } & \multicolumn{3}{|c|}{ PLEISTOCENE } & \multirow{2}{*}{$\begin{array}{c}\text { REFERENCES } \\
\text { AUTHORS (publication year) }\end{array}$} \\
\hline & MN 14 & MN 15 & MN 16 & MN 17 & Early & Middle & \\
\hline Czech Republic: & & & & & & & FEJFAR \& SABOL (2005) \\
\hline Měňany 3 & & $\mathrm{x}$ & $x$ & & & & CERMAK et al. $(2007,2008)$ \\
\hline Vitošov & & $x$ & $\mathrm{x}$ & & & & CERMAK et al. $(2007,2008)$ \\
\hline Ctiněves 1 & & & & $\mathrm{x}$ & & & FEJFAR \& HORACEK (1983) \\
\hline Mokra 1 & & & & & $x$ & & FEJFAR \& HORACEK (1983) \\
\hline Chlum 6 & & & & & $\mathrm{x}$ & & FEJFAR \& HORACEK (1983) \\
\hline Holštejn & & & & & $\mathrm{x}$ & & MUSIL (1966), FEJFAR \& HORACEK (1983) \\
\hline Stránská skála & & & & & $x$ & & RZEBIK-KOWALSKA (1972) \\
\hline \multicolumn{8}{|l|}{ Hungary: } \\
\hline Osztramos $1,2,3,4,7,8,14$ & $x$ & & $x$ & $x$ & $x$ & $x$ & $\begin{array}{l}\text { JÁNOSSY (1973, 1978), JÁNOSSY \& KORDOS (1977), } \\
\text { REUMER (1984), JÁNOSSY (1986) }\end{array}$ \\
\hline Csarnóta 1,2,4 & & $\mathrm{x}$ & & $\mathrm{x}$ & & & KRETZOI (1956, 1959), REUMER (1984) \\
\hline Beremend $1,2,3,4,5,8,9,11,15$ & & & $x$ & $\mathrm{x}$ & $\mathrm{x}$ & & $\begin{array}{l}\text { PETÉNYI (1864), KRETZOI (1956), JÁNOSSY (1986), } \\
\text { PAZONYI (2006) }\end{array}$ \\
\hline Villány $1,2,3,5,6,7,8,11$ & & & & $\mathrm{x}$ & $\mathrm{x}$ & $x$ & $\begin{array}{l}\text { KORMOS (1934), KRETZOI (1956), REUMER (1984), } \\
\text { JÁNOSSY (1986), PAZONYI (2006) }\end{array}$ \\
\hline Dunaalmás 4 & & & & $x$ & $\mathrm{x}$ & & JÁNOSSY (1986) \\
\hline Nagyharsányhegy 2,3,4,5 & & & & $x$ & $\mathrm{x}$ & & KRETZOI (1956), JÁNOSSY (1986) \\
\hline Újlak Hill & & & & & $\mathrm{x}$ & & JÁNOSSY (1986) \\
\hline Süttő 19 & & & & & $\mathrm{x}$ & & PAZONYI et al. (2014) \\
\hline Somssich Hill 1,2 & & & & & $\mathrm{x}$ & & $\begin{array}{l}\text { JÁNOSSY (1983, 1986, 1999), HÍR (1998), MÉSZÁROS } \\
\text { et al. (2013), PAZONYI et al. (2013a, b), PAZONYI \& } \\
\text { VIRÁG (2013a, b), SZENTESI (2013, 2014a, b), BOTKA } \\
\text { \& STRICZKY (2014), BOTKA \& MÉSZÁROS (2014a, b) }\end{array}$ \\
\hline Tarkő & & & & & & $\mathrm{x}$ & JÁNOSSY (1986) \\
\hline \multicolumn{8}{|l|}{ Ukraine: } \\
\hline Chortkov & & & & & $\mathrm{x}$ & & PIDOPLICKO (1956) \\
\hline Gorishnya Vygnanka & & & & & $\mathrm{x}$ & $\mathrm{x}$ & MAUL (1990) \\
\hline \multicolumn{8}{|l|}{ France: } \\
\hline Saint-Vallier & & & & $\mathrm{x}$ & & & SUAREZ \& MEIN (2004) \\
\hline Courterolles & & & & & $\mathrm{x}$ & & BROCHET et al. (1983) \\
\hline Valerots (Cote d'Or) & & & & & $\mathrm{x}$ & & CHALINE et al. (1985) \\
\hline Mas Rambault 2 & & & & & $\mathrm{x}$ & & AGUILAR et al. (2002) \\
\hline Saint-Sauveur & & & & & & $\mathrm{x}$ & CROCHET \& MICHAUX (1981) \\
\hline \multicolumn{8}{|l|}{ Slovenia: } \\
\hline Črnotiče 2 & & $x$ & $x$ & & & & HORACEK et al. (2007) \\
\hline Račišša Pečina & & & & $x$ & & & HORACEK et al. (2007) \\
\hline \multicolumn{8}{|l|}{ Croatia: } \\
\hline Razvode & & & & & $\mathrm{x}$ & & PAUNOVIC \& JAMBRESIC (1997) \\
\hline Tatinja draga & & & & & $\mathrm{x}$ & & PAUNOVIC \& JAMBRESIC (1997) \\
\hline Podumci 1 & & & & & $\mathrm{x}$ & & MAUL (1990), PAUNOVIC \& JAMBRESIC (1997) \\
\hline \multicolumn{8}{|l|}{ Russia: } \\
\hline Uryv-Pokrovka & & & & & $\mathrm{x}$ & $\mathrm{x}$ & AGADZHANYAN (2009) \\
\hline
\end{tabular}

Fig. 30c. Summary about the stratigraphical range of the genus Beremendia in Europe. References contain the most important publications about the localities (Czech Republic, Hungary, Ukraine, France, Slovenia, Croatia and Russia) 
It should be noted that BotKA \& MÉszÁRos (in press) gave a figure on the MNI of $B$. fissidens teeth by layers from Somssich Hill 2 site. These data were completed with some specimens, yielded by the present studies. Otherwise some teeth should have been re-determined as $B$. minor. That is why the data of Table 3 are somewhat different from Figure 4 of BотKA \& MÉszáros (in press).

Table 3. Occurrences of Beremendia species in the layers of the Somssich Hill 2 locality, with the

\begin{tabular}{|c|c|c|c|c|c|}
\hline Layers & $\begin{array}{l}\text { MNI of } B . \\
\text { fissidens }\end{array}$ & $\begin{array}{l}\text { MNI of } B \text {. } \\
\text { minor }\end{array}$ & Layers & $\begin{array}{l}\text { MNI of } B . \\
\text { fissidens }\end{array}$ & $\begin{array}{l}\text { MNI of } B \text {. } \\
\text { minor }\end{array}$ \\
\hline 1 & - & - & 26 & 1 & - \\
\hline 2 & - & 1 & 27 & 3 & - \\
\hline 3 & 1 & - & 28 & 3 & - \\
\hline 4 & 1 & 1 & 29 & - & - \\
\hline 5 & 5 & 2 & 30 & 3 & - \\
\hline 6 & 1 & 1 & 31 & 2 & - \\
\hline 7 & 1 & - & 32 & 3 & - \\
\hline 8 & 1 & - & 33 & 1 & - \\
\hline 9 & 1 & - & 34 & 1 & - \\
\hline 10 & - & - & 35 & 1 & 1 \\
\hline 11 & 2 & - & 36 & 1 & - \\
\hline 12 & 2 & - & 37 & 1 & - \\
\hline 13 & 3 & 1 & 38 & 2 & - \\
\hline 14 & 2 & 1 & 39 & 1 & - \\
\hline 15 & 4 & - & 40 & 1 & - \\
\hline 16 & - & - & 41 & 1 & - \\
\hline 17 & - & - & 42 & 1 & - \\
\hline 18 & 1 & - & 43 & 1 & - \\
\hline 19 & - & - & 44 & 1 & - \\
\hline 20 & 1 & - & 45 & 1 & - \\
\hline 21 & - & - & 46 & 1 & - \\
\hline 22 & - & - & 47 & 1 & - \\
\hline 23 & - & - & 48 & - & - \\
\hline 24 & 1 & - & 49 & - & - \\
\hline \multirow[t]{2}{*}{25} & 2 & - & 50 & 1 & - \\
\hline & & & & 61 & 8 \\
\hline
\end{tabular}




\section{Palaeobiogeography}

Genus Beremendia was an opportunistic element in the Plio-Pleistocene faunas of Eurasia. Due to the successful strategy it became very frequent in the Early Pleistocene. The genus contains four valid species (B. fissidens, B. minor, B. pohaiensis (Kowalski et Li) and B. jiangnanensis). B. fissidens (Early PlioceneMiddle Pleistocene) and B. minor (Early Pliocene-Early Pleistocene) represented the genus in Europe, while the other two species, namely B. pohaiensis (Middle Pliocene-Early Pleistocene) and B. jiangnanensis (Early Pleistocene) were widespread in Asia (Fig. 27).

Beremendia remains are known from more than 150 localities of 20 countries from Europe. The genus had a wide distribution from the Iberian Peninsula to the Urals and from the British Isles to Central Italy and Greece (Figs 30a-c).

The first appearance of the genus was probably in Central Europe (MN14 of Poland and Hungary). The spreading of the genus started from here in the Middle Pliocene (MN15). During the Late Pliocene (MN16) the genus expanded to a south-southwest direction (Spain, Italy and certainly Southern France but in the latter area there are no evidences for the genus yet, only from MN17). In the earliest Pleistocene (MN17) we can see a northern transgression of Beremendia shrews to the Netherlands and Southern England. The genus reached its maximal distribution in the Early Pleistocene. From this period some localities are known in Ukraine and Russia, too (Figs 28, 30a-c).

In the Middle Pleistocene of Europe B. fissidens was the last representative of the genus and this species became extinct until the middle part of the Middle Pleistocene. The youngest occurrences of the genus are in Poland (Kozi Grzbiet $2-700 \mathrm{ka}$, StefaniaK et al. 2009) and in Hungary (Tarkő - $350 \mathrm{ka}$, JÁNossy 1986) as well (Figs $27-30 a-c)$.

Acknowledgements - The work was supported by the Hungarian Scientific Research Found (OTKA K104506 project). The authors are indebted to the members of the OTKA Research Team, mainly to Piroska Pazonyi (project leader), Zoltán Szentesi, Mihály Gasparik and Attila Virág for their useful help and valuable suggestions. Special thanks to Krisztina Buczkó for her kind help in making the SEM photos and to Piroska Pazonyi for her useful reviewer comments.

\section{REFERENCES}

Adrover A. 1986: Nuevas faunas de roedores en el Mio-Plioceno continental de la región de Teruel (Espańa). Interés bioestratigráfico y paleoecológico. - Instituto de Estudios Turolenses, 423 pp. Agadzhanyan A. K. 2009: The Pliocene and Pleistocene small mammals of the Russian Plain. Trudy Paleontologicheskogo Instituta, $289 \mathrm{pp}$. 
Aguilar J.-P., Crochet J.-Y., Hebrard O., Le Strat P., Michaux J., Pedra S. \& Sigé B. 2002: Les micromammifères de Mas Rambault 2, gisement karstique du Pliocène supérieur du Sud de la France: âge, paléoclimat, géodynamique. - Géologie de la France 4: 17-37.

Agustí J., Santos-Cubedo A., Furió M., De Marfá R., Blain H.-A., Oms O. \& Sevilla P. 2011: The late Neogene-early Quaternary small vertebrate succession from the AlmenaraCasablanca karst complex (Castellón, Eastern Spain): Chronologic and paleoclimatic context. - 2uaternary International 243: 183-191. http://dx.doi.org/10.1016/j.quaint.2010.11.016

Antoñanzas R. L. \& Cuenca-Bescós G. 2002: The Gran Dolina site (Lower to Middle Pleistocene, Atapuerca, Burgos, Spain): new palaeoenvironmental data based on the distribution of small mammals. - Palaeogeography, Palaeoclimatology, Palaeoecology 186: 311-334. http://dx.doi.org/10.1016/S0031-0182(02)00515-1

Bennàsar M., Cáceres I., Cuenca-Bescós G., Huguet R., Blain H.-A. \& Rofes J. 2014: Exceptional biting capacities of the Early Pleistocene fossil shrew Beremendia fissidens (Soricidae, Eulipotyphla, Mammalia): new taphonomic evidence. - Historical Biology 5: 1-9. http://dx.doi.org/10.1080/08912963.2014.918611

Bolliger T., ENGESSER B. \& WeidMann M. 1993: Première dècouverte de mammifères pliocènes dans le Jura Neuchatelois. - Eclogae Geologica Helvetica 86: 1031-1068.

Bosák P., Glazek J., Horáčex I. \& Szynkiewicz A. 1982: New Locality of Early Pleistocene Vertebrates from Zabia Cave at Podlesice, Central Poland. - Acta Geologica Polonica 32: 217-226.

Bot KA D. \& MÉszÁros L. 2014: A Somssich-hegy 2-es lelőhely alsó-pleisztocén Soricidae faunája. [The Lower Pleistocene Soricidae fauna of the Somssich Hill 2 locality]. - In: BosNAKOFF M. \& Dulai A. (eds): Program, Elöadás-kivonatok, Kirándulásvezetö, 17. Magyar Öslénytani Vándorgyülés, Győr, pp. 10-11. (in Hungarian)

Bot KA D. \& MÉszáros L. in press: A Somssich-hegy 2-es lelőhely (Villányi-hegység) alsó-pleisztocén Beremendia fissidens (Mammalia, Soricidae) maradványainak taxonómiai és paleoökológiai vizsgálata. [Taxonomic and palaeoecological studies on the Lower Pleistocene Beremendia fissidens (Mammalia, Soricidae) remains of the Somssich Hill 2 locality (Villány Mountains)]. - Földtani Közlöny 145(1). (in Hungarian, with English abstract)

Bot KA D. \& STRICZ KY L. 2014: Soricidae and Gliridae fauna of the late Early Pleistocene Somssich Hill 2 locality (South Hungary). - Acta Mineralogica-Petrographica Abstract Series 8: 12.

Brochet G., Chaline J. \& Poplin F. 1983: Courterolles (Yonne), une faune interglaciaire à hippopotame (Waalien?) et une microfaune steppique à Allophaiomys (Ménapien?) du Pleistocène inférieur. - Memoires de la Société Préhistorique de la France 16: 15-18.

Carls N. \& Rabeder G. 1988: Arvicolids (Rodentia, Mammalia) from the Earliest Pleistocene of Schernfeld (Bavaria). - Beiträge zur Paläontologie von Österreich 14: 123-237.

ČERMÁK S., WAGNER J., FeJfFAR O. \& HORÁČEK I. 2007: New Pliocene localities with micromammals from the Czech Republic: a preliminary report. - Fossil Record 10(1): 60-68. http://dx.doi.org/10.1002/mmng.200600019

Čermák S., WAgner J., Fejfar O. \& HoráčEK I. 2008: Updated record of the Pliocene mammalian assemblages from the Czech and Slovak Republic. - Volume of Abstracts, 6th Meeting of European Association of Vertebrate Palaeontologists, p. 99.

Chaline J., Renault-Miskovsky J., Brochet G., Clement-Dels R., Jammot D., MourerChauvire C., Bonvalot J., Lang J., Leneuf N. \& Pascal A. 1985: Laven des Valerots (Nuits-Saint-Georges, Côte-d'Or), site de référence du Pléistocène inférieur. - Revue de Géographie Physique et de Géologie Dynamique 2(2): 109-118.

Crochet J.-Y. \& Michaux J. 1981: Une faune de vertébrés du Pleistocène moyen sur le Causse du Larzac: Saint-Saveur, près Nant (Aveyron). - Paléobiologie Continentale 12(1): 131-143.

CUencA-Bescós G. \& Rofes J. 2007: First evidence of poisonous shrews with an envenomation apparatus. - Naturwissenschaften 94: 113-116. http://dx.doi.org/10.1007/s00114-006-0163-5 
Cuenca-Bescós G., Rofes J. \& Garcia-Pimienta J. 2005: Environmental change across the Early-Middle Pleistocene transition: small mammalian evidence from the Trinchera Dolina cave, Atapuerca, Spain. - Geological Society, London, Special Publications 247(1): 277-286. http://dx.doi.org/10.1144/GSL.SP.2005.247.01.16

Cuenca-Bescós G., Rofes J., López-García J. M., Blain H.-A., De Marfá R. J., GalindoPellicena M. A., Bennásar-Serra M. L., Melero-Rubio M., Arsuaga J. L., Bermúdez De CASTRo J. M. \& CARBonell E. 2010: Biochronology of Spanish Quaternary small vertebrate faunas. - 2uaternary International 212: 109-119. http://dx.doi.org/10.1016/j.quaint.2009.06.007

Cuenca-Bescós G., Rofes J., López-García J. M., Blain H.-A., Rabal-Garcés R., Saulué V., Arsuaga J. L., Bermúdez de Castro J. M. \& CARbonell E. 2013: The small mammals of Sima del Elefante (Atapuerca, Spain) and the first entrance of Homo in Western Europe. Quaternary International 295: 28-35. http://dx.doi.org/10.1016/j.quaint.2011.12.012

Dahlmann T. 2001: Die Kleinsäuger der unterpliozänen Fundstelle Wölfersheim in der Wetterau (Mammalia: Lipotyphla, Chiroptera, Rodentia). - Courier Forschungsinstitut Senckenberg 227: 1-129.

Dahlmann T. \& SтоRсн G. 1996: Eine pliozäne (ober-ruscinische) Kleinsäugerfauna aus Gundersheim, Rheinhessen. 2. Insektenfresser: Mammalia, Lipotyphla. - Senckenbergiana lethaea 76(1-2): 181-191.

Dенм R. 1962: Altpleistocäne Säuger von Schernfeld bei Eichstätt in Bayern. - Mitteilungen der Bayerischen Staatssammlung für Paläontologie und Historische Geologie 2: 17-61.

Doukas C. S. 2005: Greece. - In: Hoek Ostende L. W. van den, Doukas C. S. \& Reumer J. W. F. (eds): The Fossil Record of the Eurasian Neogene insectivores (Erinaceomorpha, Soricomorpha, Mammalia), Part I. - Scripta Geologica Special Issue 5: 99-112.

Engesser B. 2005: Switzerland. - In: Hoek Ostende L. W. van Den, Doukas C. S. \& Reumer J. W. F. (eds): The Fossil Record of the Eurasian Neogene insectivores (Erinaceomorpha, Soricomorpha, Mammalia), Part I. - Scripta Geologica Special Issue 5: 285-295.

FANFANi F. \& MAsini F. 1997: Insectivores (Mammalia) from the Rivoli Veronese, a Late Villanyian site in Northeastern Italy. - Bolletino della Società Paleontologica Italiana 36: 367-380.

FeJfar O. 1964: The Lower Villafranchian Vertebrates from Hajnáčka near Filákovo in Southern Slovakia. - Rozpravy Ústredního ústavu geologického 30: 1-115.

FEJFAR O. 1966: Die plio-pleistozänen Wirbeltierfaunen von Hajnacka und Ivanovce (Slowakei), ČSSR. V. Allosorex stenodus n. g. n. sp. aus Ivanovce. - Neues Jabrbuch für Geologie und Paläontologie, Abhandlungen 123(3): 221-248.

FEJFAR O. \& HorÁČEK I. 1983: Zur Entwicklung der Kleinsäugerfaunen im Villányium und AltBiharium auf dem Gebiet der ČSSR. - Schriftenreihe für Geologische Wissenschaften 19-20: 111-207.

Fejfar O. \& SABOL M. 2004: Pliocene Carnivores (Carnivora, Mammalia) from Ivanovce and Hajnáčka (Slovakia). - Courier Forschungsinstitut Senckenberg 246: 15-53.

Fejfar O. \& Sabol M. 2005: Czech Republic and Slovak Republic. - In: Hoek Ostende L. W. VAN Den, Dou Kas C. S. \& Reumer J. W. F. (eds): The Fossil Record of the Eurasian Neogene insectivores (Erinaceomorpha, Soricomorpha, Mammalia), Part I. - Scripta Geologica Special Issue 5: 51-60.

Frank C. \& RABeder G. 1997: Stranzendorf. - In: Döppes D. \& RABeder G. (eds): Pliozäne und Pleistozäne Faunen Österreichs. - Mitteilungen der Kommission für Quartärforschung der Österreichischen Akademie der Wissenschaften 10: 130-137.

Freudenthal M., Meijer T. \& Meulen A. J. van Der 1976: Preliminary report on a field campaign in the continental Pleistocene of Tegelen (The Netherlands). - Scripta Geologica 34: 1-27. 
FRIANT M. 1949: Les Musaraignes (Soricidae) quaternaires et actuelles de l'Europe occidentale. Annales de la Societe Geologique du Nord 67: 222-269.

Furió M., Agustí J., Mouskhelishvili A., Sanisidro O. \& Santos-Cubedo A. 2010: The Paleobiology of the Extinct Venomous Shrew Beremendia (Soricidae, Insectivora, Mammalia) in Relation to the Geology and Paleoenvironment of Dmanisi (Early Pleistocene, Georgia). - Journal of Vertebrate Paleontology 30(3): 928-942. http://dx.doi.org/10.1080/02724631003762930

Garcia J., Martínez K., Cuenca-Bescós G. \& Carbonell E. 2014: Human occupation of Iberia prior to the Jaramillo magnetochron (>1.07 Myr). - 2uaternary Science Reviews 98: 84-99. http://dx.doi.org/10.1016/j.quascirev.2014.05.031

Goodman S. 2008: A Dirty Dozen: Twelve P-Value Misconceptions. - Seminars in Hematology 45: 135-140. http://dx.doi.org/10.1053/j.seminhematol.2008.04.003

Gureev A. A. 1979: Insectivores (Mammalia, Insectivora): Hedgehogs, Moles, and Shrews (Erinaceidae, Talpidae, Soricidae). - In: The Fauna of the USSR, Mammals. Vol. 4, No. 2, Nauka Press, Leningrad, 503 pp. (in Russian)

HARrison D. L. \& Parfitt S. A. 2009: Fossil remains of shrews (Soricomorpha: Soricidae) and desmans (Talpidae: Desmaninae) from Norfolk, England, with biostratigraphic implications for the Plio-Pleistocene boundary in East Anglia. - Acta Zoologica Cracoviensia 52A(1-2): 61-79. http://dx.doi.org/10.3409/azc.52a_1-2.61-79

Harrison D. L., Parfitt S. A. \& STUART A. J. 2006: Occurrence of Macroneomys brachygnathus Fejfar, 1966 in the British Middle Pleistocene, with a review of the status of Beremendia fissidens (Petényi, 1864) in Britain (Mammalia, Lipotyphla, Soricidae). - Acta Zoologica Cracoviensia 49A(1-2): 119-124. http://dx.doi.org/10.3409/000000006783995553

Heller F. 1930: Eine Forest-Bed-Fauna aus der Sackdillinger Höhle (Oberpfalz). - Neues Jahrbuch für Mineralogie, Geologie und Paläontologie, Abteilung B63: 247-298.

Heller F. 1936: Eine oberpliozäne Wirbeltierfauna aus Rheinhessen. - Neues Jabrbuch für Mineralogie, Geologie und Paläontologie, Abteilung B76: 99-160.

Heller F. 1956: Ein kleiner Bär (Ursus sackdillingensis n. sp.) in der cromerischen Fauna der Sackdillinger-Höhle (Oberpfalz). - Neues Jahrbuch für Geologie und Paläontologie, Monatshefte 1955: 520-530.

HelleR F. 1963: Eine altquartäre Wirbeltierfauna des unteren Cromerium aus der nördlichen Frankenalb. - Neues Jahrbuch für Geologie und Paläontologie, Abhandlungen 118: 1-20.

Hellmund M. \& Ziegler R. 2012: A Ruscinian mammalian microfauna from a fissure filling near Sondershausen (Thuringia, Central Germany). - Swiss Journal of Palaeontology 131: 77-94. http://dx.doi.org/10.1007/s13358-011-0019-2

Hí J J. 1998: Cricetids (Rodentia, Mammalia) of the Early Pleistocene vertebrate fauna of Somssich Hill 2 (Southern Hungary, Villány Mountains). - Annales historico-naturales Musei nationalis hungarici 90: 57-89.

Hoek Ostende L. W. van den \& Furió M. 2005: Spain. - In: Hoek Ostende L. W. van den, Doukas C. S. \& Reumer J. W. F. (eds): The Fossil Record of the Eurasian Neogene insectivores (Erinaceomorpha, Soricomorpha, Mammalia), Part I. - Scripta Geologica Special Issue 5: $149-284$.

HORÁČEK I. 1985: Survey of the fossil vertebrate localities Včeláre 1-7. - Časopis pro mineralogii a geologii 30(4): 353-366.

HorÁČEK I. \& LOžEK V. 1988: Palaeozoology and the Mid-European Quaternary past: scope of the approach and selected results. - Rozpravy ČSAV, ̌̌ada matematických a prírodních véd 98: $1-102$. 
Horáček I., Mihevc A., Zupan Hajna N., Pruner P. \& Bosák P. 2007: Fossil vertebrates and paleomagnetism update of one of the earlier stages of cave evolution in the classical karst, Slovenia: Pliocene of Črnotiče II site and Račiška pečina Cave. - Acta Carsologica 36(3): 453-468. http://dx.doi.org/10.3986/ac.v36i3.179

JÁnossy D. 1973: The Boundary of the Plio-Pleistocene based on the Microvertebrates in North Hungary (Osztramos Locality 7). - Vertebrata Hungarica 14: 101-112.

Jánossy D. 1978: Larger Mammals from the Lowermost Pleistocene Fauna, Osztramos, Loc. 7 (Hungary). - Annales historico-naturales Musei nationalis hungarici 70: 69-79.

JÁnossy D. 1983: Lemming-remain from the Older Pleistocene of Southern Hungary (Villány, Somssich Hill 2). - Fragmenta Mineralogica et Palaeontologica 1 1: 55-60.

JÁnossy D. 1986: Pleistocene Vertebrate Faunas of Hungary. - Akadémiai Kiadó, Budapest, 208 pp.

JÁnossy D. 1990: Arvicolids from the Lower Pleistocene sites at Beremend 15 and Somssich-hegy 2, Hungary. - In: FeJfar O. \& HeINRICH W. D. (eds): International Symposium Evolution, Phylogeny and Biostratigraphy of Arvicolids (Rodentia,Mammalia), Geological Survey, Prague, pp. 223-230.

JÁNossY D. 1999: Újabb adatok a villányi Somssich-hegy 2. lelőhely leleteihez. [New data on the Somssich Hill 2 locality, Villány.] - Manuscript, Hungarian Natural History Museum, Budapest, pp. 1-10. (in Hungarian)

JÁNossy D. \& Kordos L. 1977: Az Osztramos gerinces lelőhelyeinek faunisztikai és karsztmorfológiai áttekintése (1975-ig). [Faunistical and karstmorphological review of palaeontological localities for vertebrates at Osztramos (Northern Hungary)]. - Fragmenta Mineralogica et Palaeontologica 8: 39-72. (in Hungarian)

Jin C.-Z. \& KaWAmura Y. 1996: The first reliable record of Beremendia (Insectivora, Mammalia) in East Asia and a revision of Peisorex Kowalski \& Li, 1963. - Transactions and Proceedings of the Palaeontological Society of Japan, New Series 182: 432-447.

Jin C.-Z., Zhang Y.-Q., Sun C.-K. \& Zheng L.-T. 2009: First Discovery of the Large Shrew, Beremendia (Insectivora, Soricidae), from the Lower Pleistocene of South China and its Paleoclimatic Implications. - Vertebrata PalAsiatica 47(2): 153-163.

Koenigswald W. V. voN 1971: Die altpleistozäne Wirbeltierfaunula aus der Spaltenfüllung Weissenburg 7 (Bayern). - Mitteilungen der Bayerischen Staatssammlung für Paläontologie und Historische Geologie 11: 117-122.

Kordos L. 1991: Villányi-hegység, Villány, alsó-pleisztocén ősgerinces lelőhelyek. [Villány Mountains, Villány, Lower Pleistocene palaeovertebrate localities]. - Geological Key Sections of Hungary, Geological Institute of Hungary, Budapest, 6 pp. (in Hungarian)

Kordos L. 1994: Revised Biostratigraphy of the Early Man Site at Vértesszőlős, Hungary. - Courier Forschungs-Institut Senckenberg 171: 225-236.

Kormos T. 1911: Canis (Cerdocyon) Petényii n. sp. és egyéb érdekes leletek Baranya megyéből. [Canis (Cerdocyon) Petényii n. sp. and some other interesting findings from Baranya County, Hungary.] - Magyar Királyi Földtani Intézet Évkönyve 19(4): 153-178. (in Hungarian)

Kormos T. 1930: Új adatok a püspökfürdői Somlyóhegy preglaciális faunájához. [New data on the praeglacial fauna of Somlyó Hill, Betfia.] - Állattani Közlemények 27: 40-62. (in Hungarian)

Kormos T. 1934: Neue Insektenfresser, Fledermäuse und Nager aus dem Oberpliozän der Villányer Gegend. - Földtani Közlöny 64: 296-321.

Kotsakis T., Abbazzi L., Angelone C., Argenti P., Barisone G., Fanfani F., Marcolini F. \& MASINI F. 2003: Plio-Pleistocene biogeography of Italian mainland micromammals. - In: Reumer J. W. F. \& Wessels W. (eds): Distribution and Migration of Tertiary Mammals in Eurasia. A Volume in Honour of Hans De Bruijn. - Deinsea 10: 313-342. 
Koufos G. D. 2001: The Villafranchian mammalian faunas and biochronology of Greece. - Bollettino della Societa Paleontologica Italiana 40: 217-223.

KowALSKI K. 1958: An early Pleistocene fauna of small mammals from Kadzielnia Hill in Kielce (Poland). - Acta Palaeontologica Polonica 3(1): 1-47.

KowALSKi K. 1960: An early Pleistocene fauna of small mammals from Kamyk (Poland). - Folia Quaternaria 1: 1-24.

KOWALS KI K. 1990: Stratigraphy of Neogene mammal chronology of Poland. - In: LindSAY E. H., FahlBusch V. \& Mein P. (eds): European Neogene Mammal Chronology. Plenum Press, New York, pp. 193-209.

Kretzor M. 1941: Weitere Beiträge zur Kenntnis der Fauna von Gombaszög. - Annales historiconaturales Musei nationalis hungarici 34: 105-139.

Kretzoi M. 1956: Die Altpleistozänen Wirbeltierfaunen des Villányer Gebirges. - Geologica Hungarica, Series Palaeontologica 27: 1-264.

Kretzor M. 1959: Insectivoren, Nagetiere und Lagomorphen der jüngstpliozänen Fauna von Csarnóta im Villanyer Gebirge (SüdUngarn). - Vertebrata Hungarica 1(2): 239-246.

KRETzO M. 1969: A magyarországi quarter és pliocén szárazföldi biosztratigráfiájának vázlata. [The sketch of the Quaternary and Pliocene terrestrial biostratigraphy of Hungary.] - Földrajzi Közlemények 17: 179-204. (in Hungarian)

Kretzor M. \& PÉCsI M. 1982: A Pannóniai-medence pliocén és pleisztocén időszakának tagolása. [The Pliocene and Pleistocene stratigraphy of the Pannonian Basin.] - Földrajzi Közlemények 30(4): 300-326. (in Hungarian)

Krolopp E. 2000: Alsó-pleisztocén Mollusca-fauna a Villányi-hegységből. [Lower Pleistocene mollusc fauna from the Villány Mts. (Southern Hungary)]. - Malakológiai Tájékoztató 18: 51-58. (in Hungarian with English abstract)

Laplana Conesa C., Amo Sanjuan O., Andres Moreno J. A., Lopez-Martinez N., Sanchez Marco A., Sanchiz F. B., Sanz Villar M. I. \& Sevilla Garcia P. 2004: Primeros datos sobre el nuevo yacimiento de microvertebrados Barranco del Monte 1 (Plioceno Superior, Concud, Teruel). - XX Jornadas de la Sociedad Espańola de Paleontología, Alcalá de Henares, 20-23 October 2004, Abstracts Volume, pp. 93-94.

Ligabue-Braun R., Verli H. \& Carlini C. R. 2012: Venomous mammals: A review. - Toxicon 59: 680-695. http://dx.doi.org/10.1016/j.toxicon.2012.02.012

Marchetti M., Parolin K. \& Sala B. 2000: The Biharian fauna from Monte La Mesa (Verona, northeastern Italy). - Acta Zoologica Cracoviensia 43(1-2): 79-105.

Marcolini F., Masini F. \& Argenti P. 2013: The rodents of the Pirro Nord fauna (Foggia, Southern Italy). - Palaeontographica Abteilung A: Paläozoologie-Stratigraphie 298(1-6): 73-85. http://dx.doi.org/10.1127/pala/298/2013/73

MAUL L. 1990: Überblick über die unterpleistozänen Kleinsäugerfaunen Europas. - 2uartärpaläontologie 8: 153-191.

MAUL L. 1996: Biochronological implications of the arvicolids (Mammalia: Rodentia) from the Pliocene and Pleistocene faunas of Neuleiningen (Rheinland-Pfalz, South Germany). - Acta Zoologica Cracoviensia 39: 349-356.

Maul L., Masini F., Abbazzi L. \& TURner A. 1998: The use of different morphometric data for absolute age calibration of some South- and Middle European arvicolid populations. - Palaeontographia Italica 85: 111-151.

Mein P., Moissenet E. \& TRUC G. 1978: Les formations continentales du Néogène Supérieur des Vallées du Júcar et du Cabriel au NE d'Albacete (Espagne). Biostratigraphie et Environnement. - Documents des Laboratoires de Géologie de la Faculté des Sciences de Lyon 72: 99-147.

MÉszáros L., BotKa D. \& Braun B. 2013: A Somssich-hegyi középső-pleisztocén Beremendia (Mammalia, Soricidae) maradványok paleoökológiai jelentősége. [Palaeoecologic importance 
of Beremendia (Mammalia, Soricidae) remains from the Middle Pleistocene Somssich Hill 2 locality.] - In: Bosna koff M., Dulai A., Vörös A. \& PÁlfy J. (eds): Program, Elöadás-kivonatok, Kirándulásvezetö, 16. Magyar Öslénytani Vándorgyülés, Orfü, pp. 24-25. (in Hungarian)

Meulen A. J. VAN Der \& Zagwijn W. H. 1974: Microtus (Allophaiomys) pliocaenicus from the Lower Pleistocene near Brielle, The Netherlands. - Scripta Geologica 21: 1-12.

Mörs T., Koenigswald W. V. von \& Hocht F. von der 1998: Rodents (Mammalia) from the late Pliocene Reuver Clay of Hambach (Lower Rhine Embayment, Germany). - Mededelingen Nederlands Instituut voor Toegepaste Geowetenschappen TNO 60: 135-159.

Musıl R. 1966: Holštejn, eine neue altpleistozäne Lokalität in Mähren. - Acta Musei Moraviae 51: 133-168.

PAunović M. \& JAmbrešić G. 1997: Review of the Results of Morphometric and Morphogenetic Analyses of Early Pleistocene Micromammals and Upper Pleistocene Cave Bears in Croatia. - Geologia Croatica 50(2): 225-230.

PAzony P. 2006: A Kárpát-medence kvarter emlösfauna közösségeinek paleoökológiai és rétegtani vizsgálata. [Palaeoecology and stratigraphy of Quaternary mammalian communities in the Carpathian Basin.] - Unpublished PhD thesis, Eötvös Loránd University, 114 pp. (in Hungarian)

Pazonyi P., Mészáros L., Szentesi Z., Gasparik M. \& Virág A. 2013a: Preliminary results of the palaeontological investigations of the late Early Pleistocene Somssich Hill 2 locality (South Hungary). - In: CAGATAY N. \& ZABCI C. (eds): Book of Abstracts of the RCMNS 2013, Istanbul Technical University, p. 270.

Pazonyi P., Mészáros L., Szentesi Z., Gasparik M. \& Virág A. 2013b: A Somssich-hegy 2-es lelőhely gerinces faunájának új kutatási eredményei. [New results of the palaeontological investigation of the Somssich Hill 2 vertebrate fauna.] - In: BosnA Koff M., DULAI A., Vörös A. \& PÁlfy J. (eds): Program, Elöadás-kivonatok, Kirándulásvezetö, 16. Magyar Öslénytani Vándorgyülés, Orfü, pp. 30-31. (in Hungarian)

Pazonyi P. \& Virág A. 2013a: A Microtus genus (Mammalia, Arvicolinae) landmark elemzése a Somssich-hegy 2-es lelőhelyről. [Landmark analysis of the genus Microtus (Mammalia, Arvicolinae) from the Somssich Hill 2 locality.] - In: Bosnakoff M., Dulai A., Vörös A. \& PÁlfy J. (eds.): Program, Elöadás-kivonatok, Kirándulásvezetö, 16. Magyar Öslénytani Vándorgyülés, Orfü, pp. 32-33. (in Hungarian)

PAZONYi P. \& VirÁg A. 2013b: Landmark analysis of first lower molars of genus Microtus from the late Early Pleistocene Somssich Hill 2 locality (South Hungary) and its evolutionary implications. - Systematics, phylogeny and palaeontology of small mammals, St. Petersburg, 11-14 November 2013, p. 10.

Pazonyi P., Kordos L., Magyari E., Marinova E., FüKöh L. \& Venczel M. 2014: Pleistocene vertebrate faunas of the Süttő Travertine Complex (Hungary). - Quaternary International 319: 50-63. http://dx.doi.org/10.1016/j.quaint.2013.02.031

PeTÉNYi S. J. 1864: A beremendi mészkőbánya természetrajz- és őslénytanilag leírva. Hátrahagyott munkái. [Geological and palaeontological description of the Beremend limestone quarry. Posthumus works.] - Magyar Tudományos Akadémia kiadása 1: 35-81. (in Hungarian)

PIDOPLICH Ko I. G. 1956: Materials to the study of fossil faunas of RSR Ukraine. - Akademia Nauk URSR 2: 1-236. (In Ukrainian)

Popov V. V. 2003: Late Pliocene Soricidae (Insectivora, Mammalia) from Varshets (North Bulgaria). - Acta Zoologica Cracoviensia 46: 43-72.

RÂDULESCU C. \& KISGYÖRGY Z. 1970: Contribution à la connaissance de la faune de mammifères villafranchiens de Căpeni-Vîrghiş. - Aluta 2: 11-23.

RÂDULESCU C. \& SAMSON P. M. 2001: Biochronology and evolution of the Early Pliocene to the Early Pleistocene mammalian faunas of Romania. - Bollettino della Societa Paleontologica Italiana 40(2): 285-292. 
Razali N. M. \& WAH Y. B. 2011: Power comparisons of Shapiro-Wilk, Kolmogorov-Smirnov, Lilliefors and Anderson-Darling tests. - Journal of Statistical Modeling and Analytics 2(1):21-33.

Repenning C. A. 1967: Subfamilies and genera of the Soricidae. - Geological Survey Professional Paper 565: 1-74.

Reumer J. W. F. 1984: Ruscinian and early Pleistocene Soricidae (Insectivora, Mammalia) from Tegelen (The Netherlands) and Hungary. - Scripta Geologica 73: 1-173.

Reumer J. W. F. 2005: The Netherlands. - In: Hoek Ostende L. W. van den, Doukas C. S. \& Reumer J. W. F. (eds): The Fossil Record of the Eurasian Neogene insectivores (Erinaceomorpha, Soricomorpha, Mammalia), Part I. - Scripta Geologica Special Issue 5: 113-118.

Reumer J. W. F. \& Doukas C. S. 1985: Early Pleistocene Insectivora (Mammalia) from Tourkobounia (Athens, Greece). - Proceedings Koninklijke Nederlandse Akademie van Wetenschappen B88(1): 111-121.

Reumer J. W. F. \& Hordij L. W. 1999: Pleistocene Insectivora (Mammalia) from the Zuurland boreholes near Rotterdam, The Netherlands. - In: Reumer J. W. F. \& DE Vos J. (eds): Elephants have a snorkel! Papers in honour of Paul Yves Sondaar. - Deinsea 7: 253-281.

Reumer J. W. F., Mayhew D. F. \& van Veen J. C. 2005: Small mammals from the Late Pliocene/ Early Pleistocene Oosterschelde dredgings. - Deinsea 11: 103-118.

Rofes J. \& Cuenca-Bescós G. 2009: First record of Beremendia fissidens (Mammalia, Soricidae) in the Pleistocene of the Iberian Peninsula, with a review of the biostratigraphy, biogeography and palaeoecology of the species. - Comptes Rendus Palevol 8: 21-37. http://dx.doi.org/10.1016/j.crpv.2008.08.004

Ruiz-Bustos A. \& SesÉ C. 1985: Evolución de los generos Mimomys, Arvicola y Allophaiomys (Arvicolidae, Rodentia, Mammalia) en el Plioceno y Pleistoceno de la Peninsula Ibérica. Estudios geologicos 41: 99-104.

RZEBi K-KowALS KA B. 1972: The Insectivora from Stránská Skála near Brno. - Anthropos 20: 65-70.

Rzebik-Kowalska B. 1976: The Neogene and Pleistocene insectivores (Mammalia) of Poland. III. Soricidae: Beremendia and Blarinoides. - Acta Zoologica Cracoviensia 22(12):359-385.

RzeBi K-KowALsKA B. 1994: Pliocene and Quaternary Insectivora (Mammalia) of Poland. - Acta Zoologica Cracoviensia 37(1): 77-136.

RZEBi K-KowALs Ka B. 2000: Insectivora (Mammalia) from the Early and early Middle Pleistocene of Betfia in Romania. I. Soricidae Fischer von Waldheim, 1817. - Acta Zoologica Cracoviensia 43(1-2): 1-53.

Rzebi K-Kowals Ka B. 2002: The Pliocene and Early Pleistocene Lipotyphla (Insectivora, Mammalia) from Romania. - Acta Zoologica Cracoviensia 45(2): 251-281.

Rzebik-Kowalska B. 2005a: Poland. - In: Hoek Ostende L. W. van den, Doukas C. S. \& Reumer J. W. F. (eds): The Fossil Record of the Eurasian Neogene insectivores (Erinaceomorpha, Soricomorpha, Mammalia), Part I. - Scripta Geologica Special Issue 5: 119-134.

Rzebik-Kowalska B. 2005b: Romania. - In: Hoek Ostende L. W. van den, Doukas C. S. \& Reumer J. W. F. (eds): The Fossil Record of the Eurasian Neogene insectivores (Erinaceomorpha, Soricomorpha, Mammalia), Part I. - Scripta Geologica Special Issue 5: 135-147.

RzEBIK-KowALS KA B. 2009: Biodiversity of Polish fossil insectivores (Erinaceomorpha, Soricomorpha, Insectivora, Mammalia) compared to the European and global faunas. - Institute of Systematics and Evolution of Animals, Polish Academy of Sciences, Kraków, 123 pp.

RzeBiK-KowALSKA B. 2013: Sorex bifidus n. sp. and the rich insectivore mammal fauna (Erinaceomorpha, Soricomorpha, Mammalia) from the Early Pleistocene of Żabia Cave in Poland. - Palaeontologia Electronica 16(2/12A): 1-35.

Rzebik-Kowalska B. \& Popov V. V. 2005: Bulgaria. - In: Hoek Ostende L. W. van den, Doukas C. S. \& Reumer J. W. F. (eds): The Fossil Record of the Eurasian Neogene insecti- 
vores (Erinaceomorpha, Soricomorpha, Mammalia), Part I. - Scripta Geologica Special Issue 5: 31-35.

ShAPIRO S. S. \& WiLK M. B. 1965: An analysis of variance test for normality (complete samples). - Biometrika 52(3-4): 591-611.

Stefaniak K., Tyc A. \& Socha P. (eds) 2009: Karst of the Częstochowa Upland and of the Eastern Sudetes: palaeoenvironments and protection. - Studies of the Faculty of Earth Sciences University of Silesia, Wroclaw, 535 pp.

STUART A. J. 1980: The vertebrate fauna from the interglacial deposits at Sugworth, near Oxford. - Philosophical Transactions of the Royal Society of London B289: 87-97.

SuÁrez E. M. \& Mein P. 2004: The Late Pliocene locality of Saint-Vallier (Drôme, France). Eleven micromammals. - Geobios 37: 115-125. http://dx.doi.org/10.1016/S0016-6995(04)80011-1

Sulims Ki A. 1959: Pliocene insectivores from Węże. - Acta Palaeontologica Polonica 4: 119-173.

SulimsKi A. 1962: Supplementary studies on the insectivores from Węże 1 (Poland). - Acta Palaeontologica Polonica 7: 441-502.

SZEntesi Z. 2013: Egy középső-pleisztocén kétéltủ fauna a Villányi-hegységből. [Middle Pleistocene amphibian fauna from the Villány Mountains.] - In: BosNA KOFF M., DULAI A., Vörös A. \& PÁlfy J. (eds): Program, Elöadás-kivonatok, Kirándulásvezetö, 16. Magyar Öslénytani Vándorgyülés, Orfü, pp. 38-39. (in Hungarian)

SZENTESI Z. 2014a: Előzetes eredmények a késő kora-pleisztocén korú Somssich-hegy 2 (Villány, Villányi-hegység) gerinces lelőhely hüllőinek vizsgálatában. [Preliminary results on the reptile fauna from the late Early Pleistocene Somssich Hill 2 locality (Villány Mountains)]. In: Bosnakoff M. \& Dulai A. (eds): Program, Elöadás-kivonatok, Kirándulásvezetö, 17. Magyar Öslénytani Vándorgyülés, Győr, pp. 35-36. (in Hungarian)

SZentesi Z. 2014b: Előzetes eredmények a késői kora-pleisztocén Somssich-hegy 2 (Villányihegység) ősgerinces-lelőhely kétéltűinek vizsgálatában. [Preliminary results on a study of amphibians of the late Early Pleistocene Somssich Hill 2 palaeovertebrate locality (Villány Mountains)]. - Földtani Közlöny 144(2): 165-174. (in Hungarian, with English abstract)

TerzeA E. 1973: À propos d'une faune villafranchienne finale de Betfia (Bihor, Roumanie). - Travaux de l'Institute de Spéologie „Émile Racovitza” 12: 229-242.

Terzea E. 1983: Pliomys "lenki"(Heller, 1930) (Rodentia, Mammalia), dans le Pléistocène de Roumanie. - Travaux de l'Institute de Spéologie „Émile Racovitza” 22: 65-80.

Tobien H. 1977: Fauna. - In: Boenigk W., Brelie G. von Der, Brunnacker K., Kempf E. K., Koci A., Schirmer W., Stadler G., Streit R. \& Tobien H. (eds): Jungtertiär und Quartär im Horloffgraben/Vogelsberg. - Geologische Abhandlungen Hessen 75: 65-68.

Tobien H. 1980: Säugerfaunen von der Grenze Pliozän/Pleistozän in Rheinhessen. 1. Die Spaltenfüllungen von Gundersheim bei Worms. - Mainzer geowissenschaftliche Mitteilungen 8: 209-218.

WEERD A. VAN DE 1979: Early Ruscinian rodents and lagomorphs (Mammalia) from the lignites near Ptolemais (Macedonia, Greece). - Proceedings Koninklijke Nederlandse Akademie van Wetenschappen 82: 127-170.

Ziegler R. \& Daxner-Höck G. 2005: Austria. - In: Hoek Ostende L. W. van den, Doukas C. S. \& ReUMER J. W. F. (eds): The Fossil Record of the Eurasian Neogene insectivores (Erinaceomorpha, Soricomorpha, Mammalia), Part I. - Scripta Geologica Special Issue 5: 11-29.

Ziegler R., Dahlmann T., Reumer J. W. F. \& Storch G. 2005: Germany. - In: Hoek Ostende L. W. van den, Doukas C. S. \& Reumer J. W. F. (eds): The Fossil Record of the Eurasian Neogene insectivores (Erinaceomorpha, Soricomorpha, Mammalia), Part I. Scripta Geologica Special Issue 5: 61-98. 